\title{
血中レカルチウム 量ノ增減ガレア ドレナリンフノ血壓作用二 及ボス影響二就テ
}

\author{
醫學士 町井 秀 成

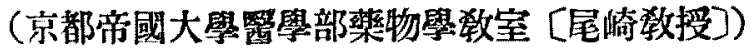

(昭和四年一月二十一日受付)

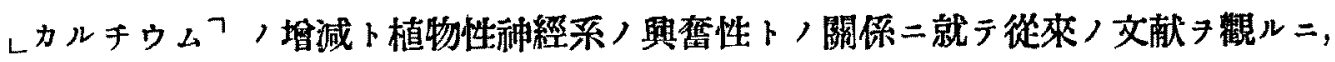

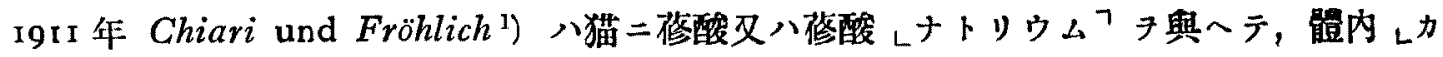

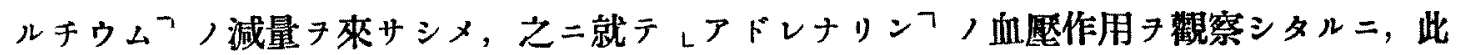
際レアドレナリン'，作用八正常時二比シ一般二强盛トナルノミナラズ，葆酸尹興へタル 䡒ニ於テハムアドレナリンフ，極メテ小量ニヨリテ血壓ハ上昇キ來サズ，却ツテ下降スル

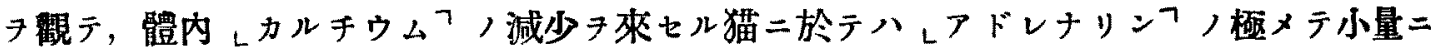

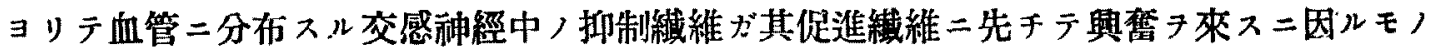
ナリト說ケリ。

本数室二於テモ，日下（1922 年）八家鬼耳殼血管及ビ蛙後肢血管整流試驗)結果， 艾感神經末梢ノ興整性ハムカルチウム 量ノ一程度ノ減少ニョリテ最モ增大シ，ソノ缺そ

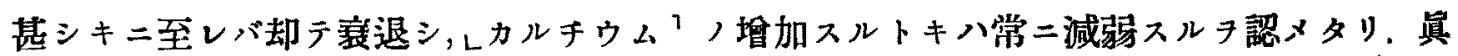

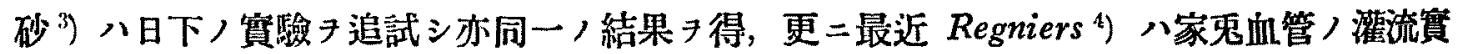

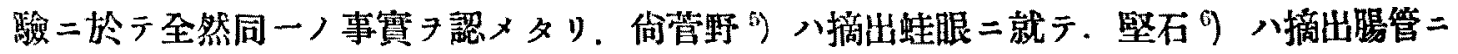
對シ,レアドレナリンフ 作用タ檢シ，日下ト一致セル結論二澾セり

以上ノ諸論二依レバ交感神經末梢, 興楿性, 從テレアドレナリン'作用ハょカルチウ

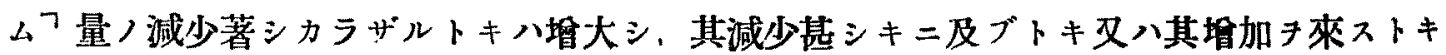
八減弱スルタ識ル

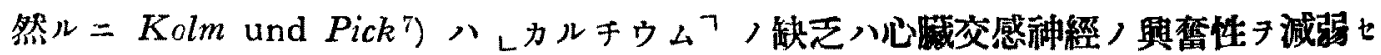




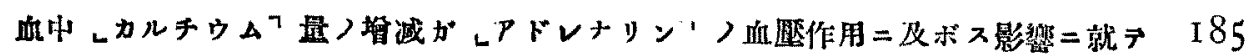

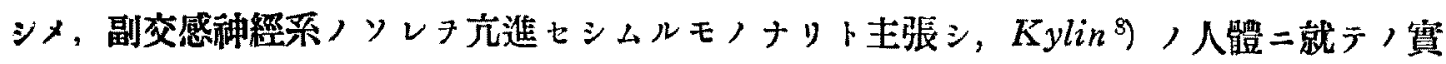

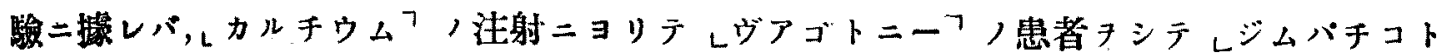
ニーフ孌ゼシムルョ得タリト云フ 又 Hollo und Weiss9) ハレカルチウムフ 注射二

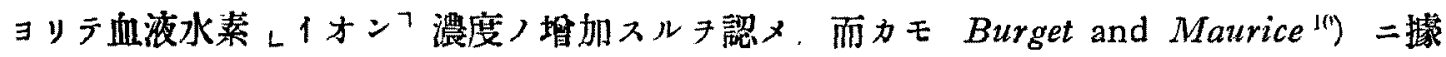

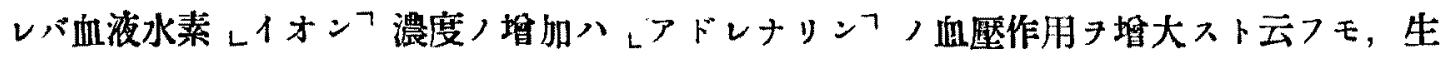

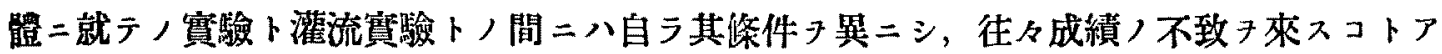

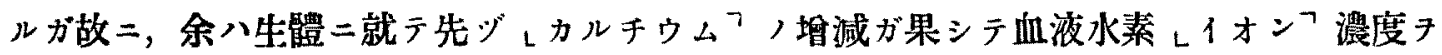

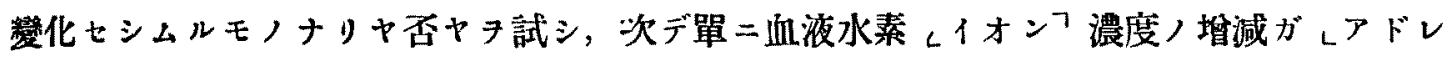
ナリンフノ血壓作用チ如何二左右スルヤチ探究シ, 最後二レカルチウムフノ增减ガレアドレ ナリンフ，血曆作用二及ボス影響タ檢シ，彼此對照シ，以テ本間題，解决二資セムトス。

\section{宽驗方法}

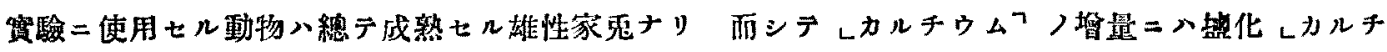

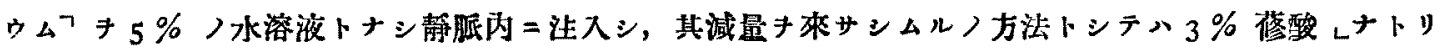

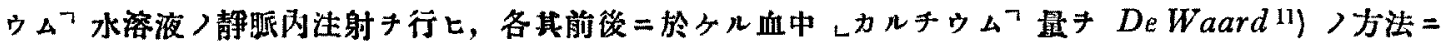
ヨリ $\boldsymbol{7}$ 定量七り

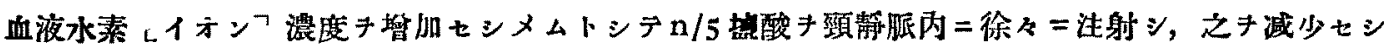

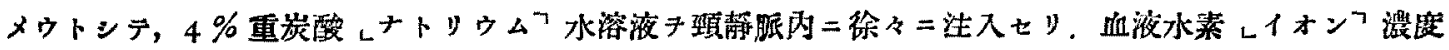
“Michaelis ${ }^{12}$ ) >瓦斯連䥊测定法ニ㨡り テ測定セり

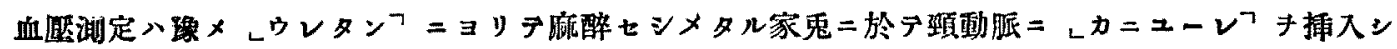

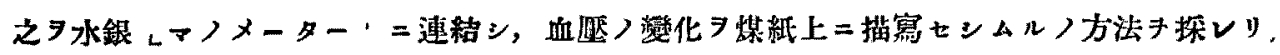

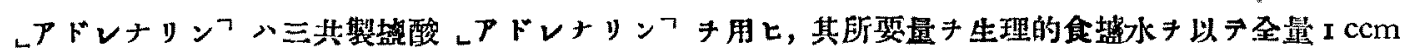
二稀釋ン，耳殼静脈ヨリI分間二注入七り

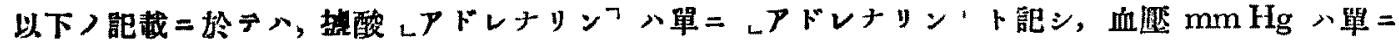
mm 卜 壾 又。

\section{宽驗成 績}

\section{I. 正常家鬼血中 レカルチウム}

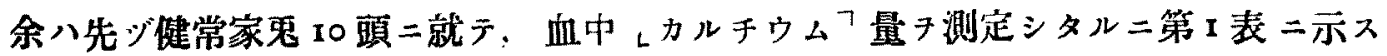
如キ成續チ得タリ。 
第 1 表 正常家鬼血中

\begin{tabular}{|c|c|c|c|}
\hline \multicolumn{3}{|c|}{ 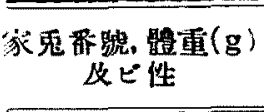 } & $\begin{array}{l}\text { 血清し力ル } \\
\text { チウム睍 } \\
\text { mg \% }\end{array}$ \\
\hline $\mathrm{I}$ & 2500 & $\boldsymbol{s}$ & 10,5 \\
\hline II & 2300 & $\hat{\delta}$ & 12,5 \\
\hline III & 2100 & $\hat{\delta}$ & II, 6 \\
\hline IV & 2300 & $\delta$ & II, 9 \\
\hline $\mathrm{V}$ & 2000 & $\delta$ & 12,4 \\
\hline VI & 2400 & 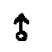 & 12,0 \\
\hline VII & 2400 & $\delta$ & I I , 5 \\
\hline VIII & 2300 & $\hat{s}$ & $\mathrm{I} 2,3$ \\
\hline IX & 2000 & $\delta$ & 12,5 \\
\hline $\mathrm{x}$ & 2100 & 占 & 10,0 \\
\hline
\end{tabular}

即于健常家鬼血清 $100 \mathrm{ccm}$ 中）レカルチウムフ 量 八最低 $10 \mathrm{mg}$, 最高 $12,5 \mathrm{mg}$ ニシテ, 此範圍内二於ヶ ル動搖ハ生理的ノモノト認メザル可ラズ.

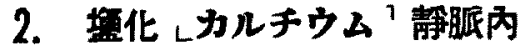
注入後ニ於ヶル血中 レカルチウムフ 量

Marianne Richter-Ouittner ${ }^{13}$ ) 八家鬼静脈内 $=$ 塩 化レカルチウムフ チ注入シテ，其前後ノ血中レカルチ ウムフ量測定シタルニ, 注入後血中レカルチウム 量ノ著明二燴加スルテ觀タリ

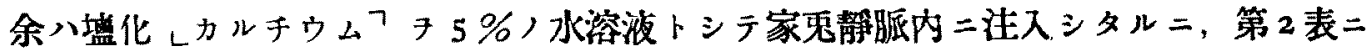
示ス如キ結果 得タリ。

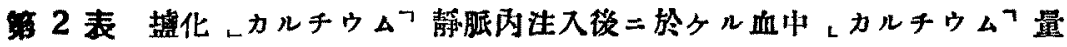

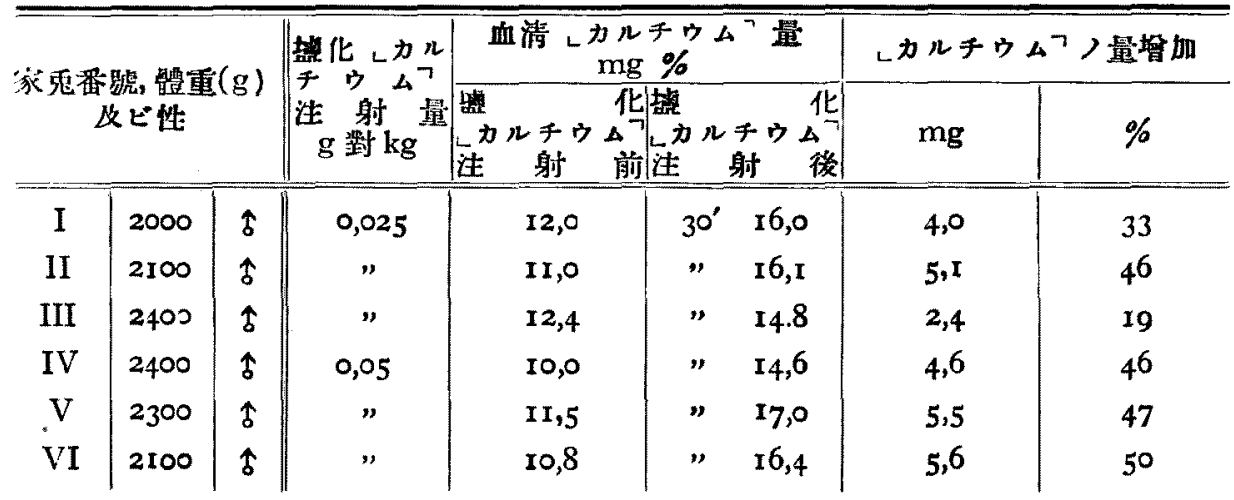

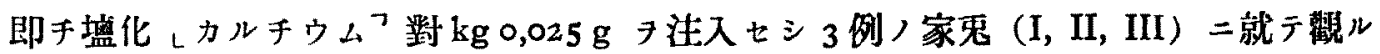

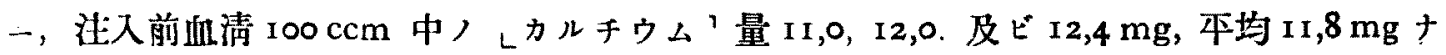
リシモノガ注入後 $3 \supset$ 分ニシテ I4,8, I6,0及ビ $16,1 \mathrm{mg}$, 平均 $15,6 \mathrm{mg}$ 二增加スルキ觀タ

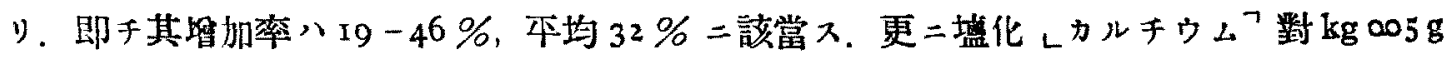

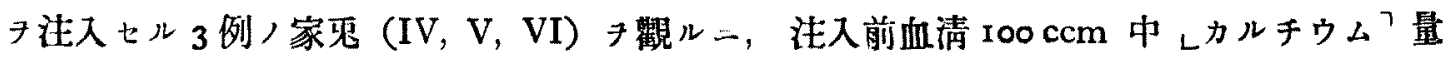

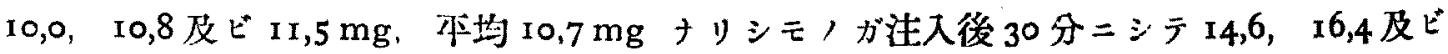
$17 \mathrm{mg}$, 平均 $16,0 \mathrm{mg}$ 二增加スル尹認メタリ. 即于其堌加ノ割合ハ 46-50\%, 本均 $48 \%=$

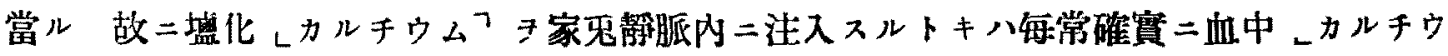


ムフ量ノ艃加テ來サシメ得ルチ識ル。

\section{3. 落酸 レナトリウム 靜胍內注入後二 於ケル血中 レカルチウム 7 量}

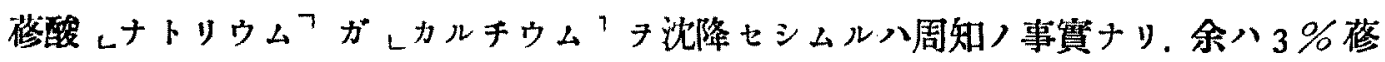

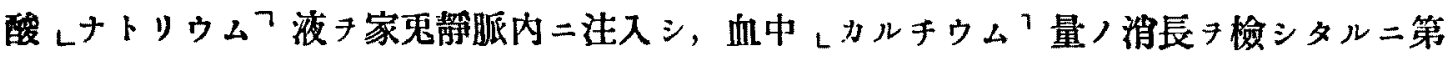
3 表ノ如キ結果尹得タリ。

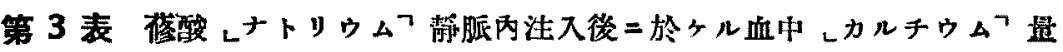

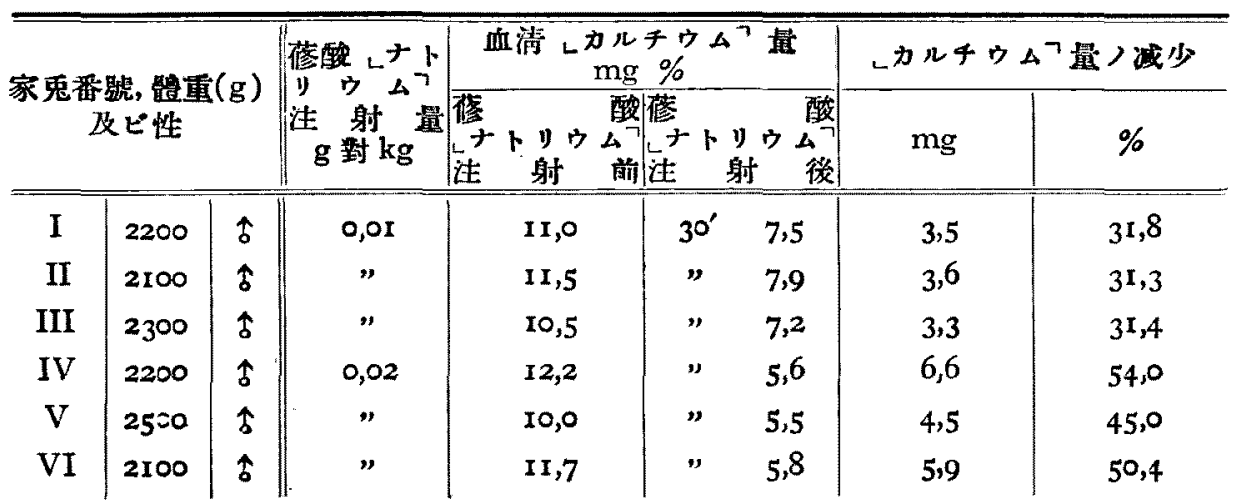

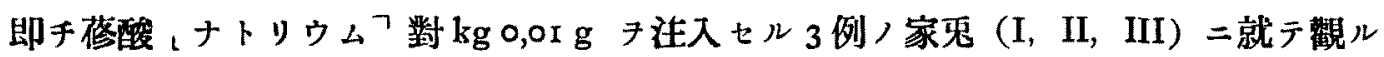

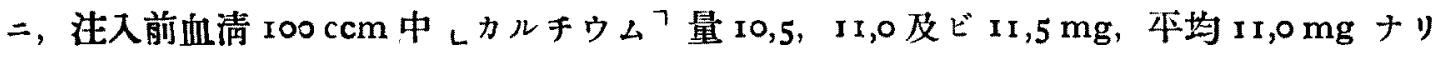
シモノカ注入後 30 分二シテ 7,2, 7,5 及ビ 7,9 mg, 平均 7,5 mg 二減少スルチ觀タリ。.之チ 減少率ニヨリテ示セバ $31,3-31,8 \%$, 平均 $31,5 \%$ ，減少二當ル. 次二葆酸 レナトリウム

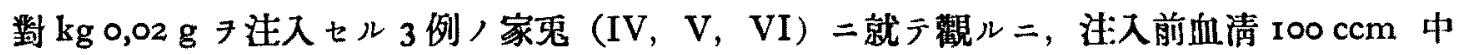

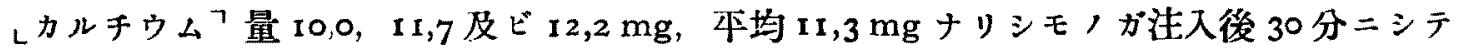
$5,5,5,5$ 及ビ $5,8 \mathrm{mg}$, 平均 5,6 mg二減少スルキ認*タリ。即チ $45-54 \%$, 本均 $49,8 \%$ ，減少二相當ス。故二葆酸レナトリウムフ夜キ家束静脈内二注入スルトキハ每常確實二血 中々カルチウムフ量ノ減少キ來シ，其注入量ノ堆加トトモニレカルチウム”量ノ減少モ亦 大トナルチ㖪ル.

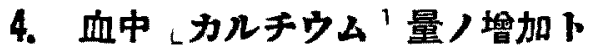 血液水素 レイオンフ 淟度}

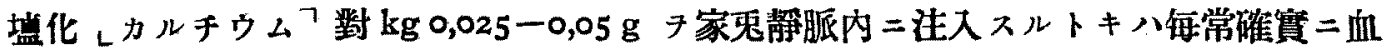




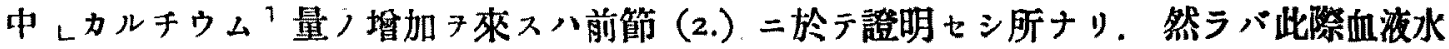

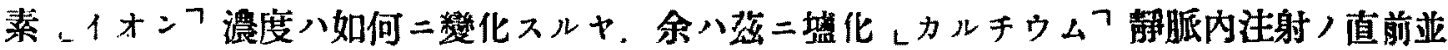

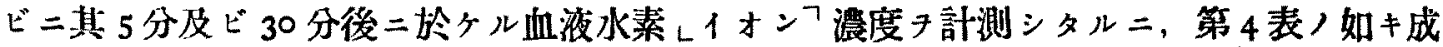

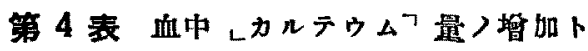
血液水素レイオンフ 澴度

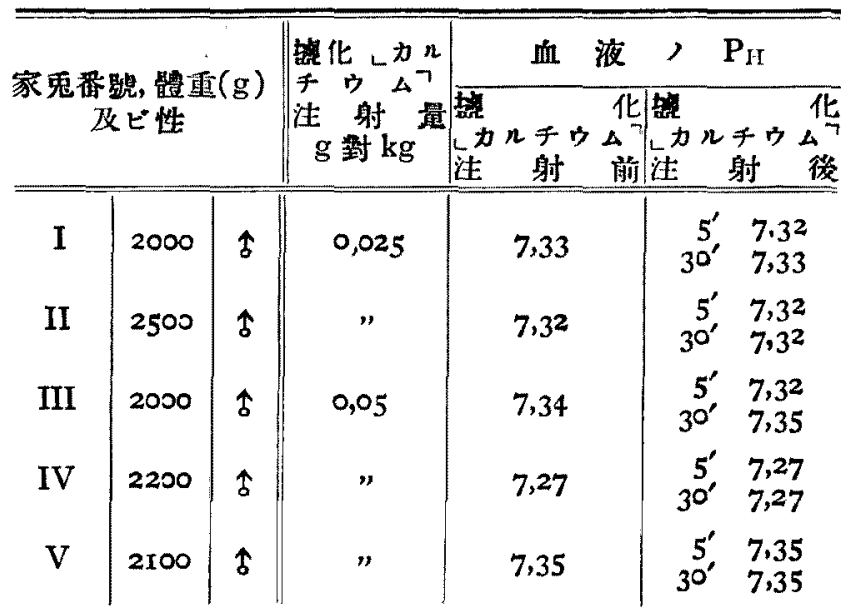

績 得タリ。

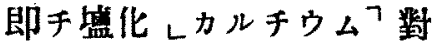
$\mathrm{kg} 0,025 \mathrm{~g} 7$ 注射七シ2 例二就 テ觀ルニ,ょカルチウム ${ }^{7}$ 注射前 血液 $\mathrm{P}_{\mathrm{H}} 7,33$ ナリシ $\mathrm{x}$ 例八拄射 後 5 分ニシテ $P_{H} 7,32$ フ示スタ 觀タレドモ， 30 分後二川 $\mathrm{P}_{\mathrm{H}}$ 7,33 二還ルチ觀タリ。他ノI例 二沽テハょカルキウムフ注射前 後二於クル血液 $\mathrm{P}_{\mathrm{H}}$ 二全ク差異

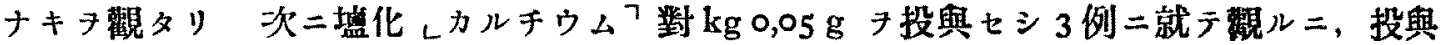
前血液 $\mathrm{P}_{\mathrm{H}} 7,34$ ナリシ I 例八投興後 5 分ニシテ $\mathrm{P}_{\mathrm{H}} 7,32$ トナリタルモ, 30 分後二ハ $\mathrm{P}_{\mathrm{H}} 7,35$

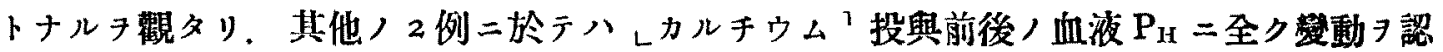
ムルコト能ハザリキ。

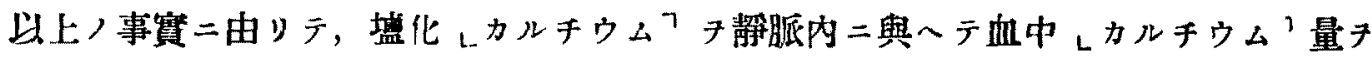
燴加セシムル二際シ，血液水素 レイオンフ濃度ハマヅ哄動セザルモノト認容セントス。

\section{5. 血中 เカルチウム' 量ノ減少、 血液水素 ᄂイオンフ 㳪度}

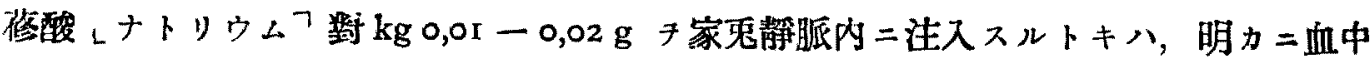
レカルチウム゙量ノ減少チ來スモノナルコトハ前節（3）二於テ證明七シ所ナリ 蓕二於テ

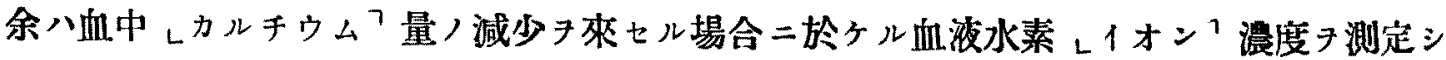
第 5 表ノ如キ結果尹得タリ。

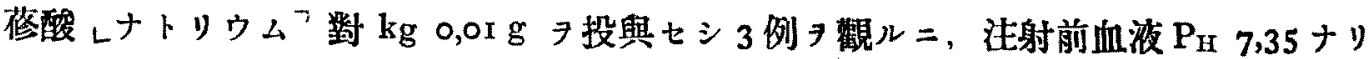

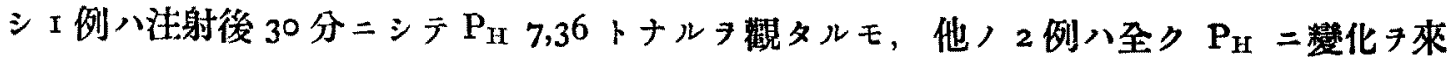

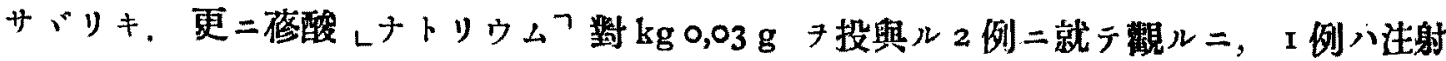




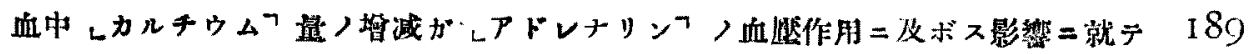

第 5 表 血中しカルチウムフ量つ牫少卜 血液水素レイォンフ 濃度

\begin{tabular}{|c|c|c|c|c|c|c|}
\hline \multirow{2}{*}{\multicolumn{3}{|c|}{ 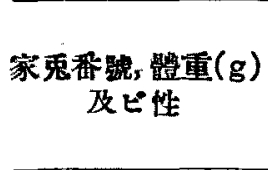 }} & \multirow{2}{*}{ 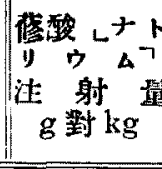 } & \multicolumn{3}{|c|}{ 血 设 $\mathbf{V}^{\prime} \mathrm{P}_{I I}$} \\
\hline & & & & 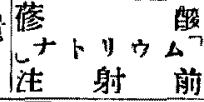 & $\mid \begin{array}{l}\text { 葆 } \\
+1 \\
\end{array}$ & 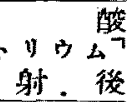 \\
\hline I & 2500 & $\boldsymbol{\delta}$ & 0,01 & 7,35 & & $\begin{array}{l}7,35 \\
7,36\end{array}$ \\
\hline II & 2100 & 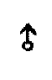 & $"$ & $7,3 \mathrm{I}$ & ${ }_{30^{\circ}}$ & $\begin{array}{l}7,3 \mathrm{I} \\
7,3 \mathrm{I}\end{array}$ \\
\hline III & 2300 & $\hat{\jmath}$ & $"$ & 7,29 & $\begin{array}{r}5^{\prime} \\
30^{\prime}\end{array}$ & $\begin{array}{r}7,29 \\
7,29\end{array}$ \\
\hline IV & 2000 & $\uparrow$ & 0,03 & 7,30 & $\begin{array}{r}5^{\prime} \\
30^{\prime}\end{array}$ & $\begin{array}{l}7,32 \\
7,30\end{array}$ \\
\hline V & 2200 & $\hat{\delta}$ & $"$ & 7,31 & $\begin{array}{r}5^{\prime} \\
30^{\prime}\end{array}$ & $\begin{array}{l}7,31 \\
7,31\end{array}$ \\
\hline
\end{tabular}

前 $P_{H} 7,30$ ナリシニ注射後 5 分 ニシテ7,32トナリタルモ, 30 分後ニハ7,30 キ示七り。他,$I$ 例八全然二裂動丹認ムルコト能 ハザリキ。

即チ葆酸レナトリウムフォ 家象䢂脈内二興へラ血中ょカル チウムフ量キ減少セシムル際血 澓水素レ1オンフ濃度ハ殆ンド 全ク變化セズト云ヒ得べシ。

\section{6. 壖酸ノ靜眽內注入後ノ血液水素 レイオンフ 濃度}

柳田 ${ }^{14}$ ) 並二鈴木 ${ }^{15}$ ) 八酸ノ非經口的投興ニヨリテ血液水素レイオンフ 濃度キ算加セシ メ得タルモ，血液反應，酸性侧二傾クヤ動物ハ其，生命ヨ保持スルコト能ハザルタ認メタ

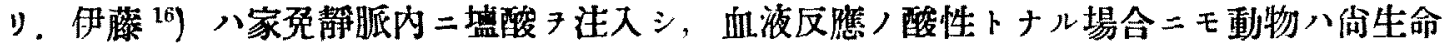

第 6 表 热酸) 静胍内注入後， 血液水素レイオンフ 濃度

\begin{tabular}{|c|c|c|c|c|c|c|}
\hline \multirow{2}{*}{\multicolumn{3}{|c|}{ 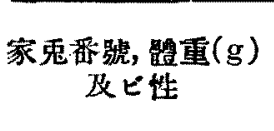 }} & \multirow{2}{*}{ 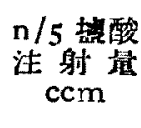 } & \multirow{2}{*}{ 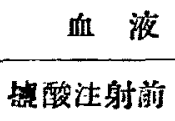 } & \multicolumn{2}{|c|}{$\supset \mathrm{P}_{\mathrm{H}}$} \\
\hline & & & & & 酶酸 & 生射後 \\
\hline I & 2100 & \& & 5 & 7,32 & $\begin{array}{r}30^{\prime} \\
60^{\prime} \\
120^{\circ}\end{array}$ & $\begin{array}{l}7,27 \\
7,30 \\
7,35\end{array}$ \\
\hline II & 2000 & 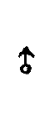 & $"$ & $7,5 \mathrm{I}$ & $\begin{array}{r}30^{\prime} \\
60^{\prime} \\
120^{\prime}\end{array}$ & $\begin{array}{l}7,40 \\
7,48 \\
7,5^{\circ}\end{array}$ \\
\hline III & 2400 & s & $"$ & 7,35 & $\begin{array}{r}30^{\prime} \\
60^{\prime} \\
120^{\prime}\end{array}$ & $\begin{array}{l}7,34 \\
7,35 \\
7,35\end{array}$ \\
\hline IV & 2200 & $\hat{\delta}$ & 10 & 7,30 & $\begin{array}{r}30^{\prime} \\
60^{\prime} \\
120^{\prime}\end{array}$ & $\begin{array}{l}7,24 \\
7,28 \\
7,29\end{array}$ \\
\hline $\mathrm{V}$ & 2100 & $\hat{\jmath}$ & $"$ & 7,32 & $\begin{array}{l}30^{\prime} \\
60^{\prime} \\
80^{\prime}\end{array}$ & $\begin{array}{l}7,22 \\
7,21 \\
\text { 死 }\end{array}$ \\
\hline VI & 2500 & $\hat{\delta}$ & $"$ & 7,70 & $\begin{array}{r}30^{\prime} \\
60^{\prime} \\
120^{\prime}\end{array}$ & $\begin{array}{l}7,20 \\
7,37 \\
7,35\end{array}$ \\
\hline
\end{tabular}

チ保テルタ記載セリ

余八家鬼静脈内 $=n / 5$ 䕄酸 5 Х小10 ccm 7 注入三，其， 注入直前並 $=30$ 分, 60 分及ビ I20分後，血液水素 ᄂイオンา 濃度 $\rightarrow$ 检查シタル 第 6 表，如 キ結果タ得タリ。

即千體重 $2000-2400 \mathrm{~g}$ ， 家思 3 䫓二就亏 $\mathrm{n} / 5$ 壒酸各 $5 \mathrm{cc}$ m $\ni$ 静脈內二洁入シタル二, 注 入前血液 $P_{H} 7,32$ ナリ 注入後 30 分 7 經テ $7,27=60$ 分後二小7,30=, 120 分後二八

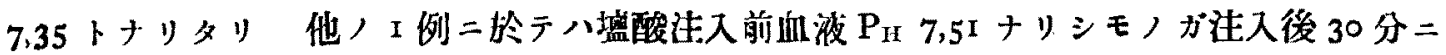




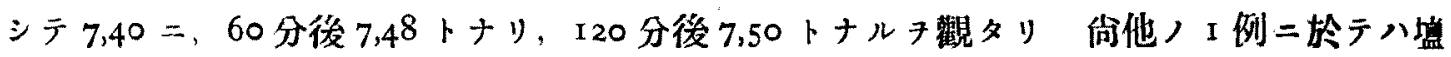
酸注入前血液 $P_{H} 7,35$ ナリシモノが注人後 30 分ニシテ 7,347示セシモ，90分後 7,35ト ナルキ認メタリ更二體量 $2100-2500 \mathrm{~g}$ ，家鬼 3 頭二就テ其静脈内 $=\mathrm{n} / 5$ 盟酸 $10 \mathrm{ccm}$

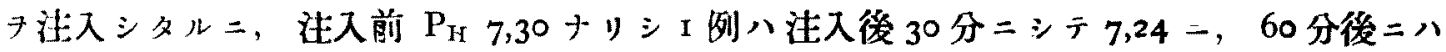

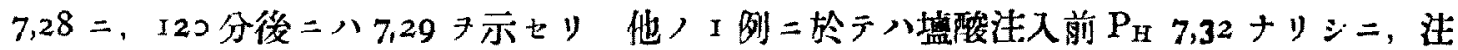

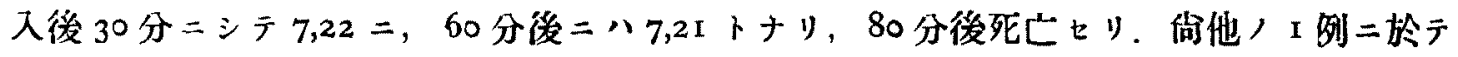
八盐睃注入前 $\mathrm{P}_{\mathrm{H}} 7,40$ ナリシ二, 注入後 30 分ニシテ 7,20 トナナリ, 60 分後二ハ7,34=, 120 分後ニハ 7,35 示セり

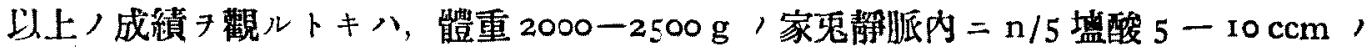

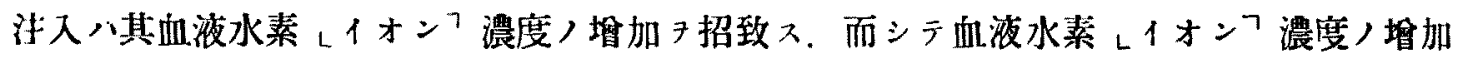
7 㙉酸注入後， 30 分，60分及ビ 120 分二就テ觀ル二，30 分後二於テ最ス著シク，又諘

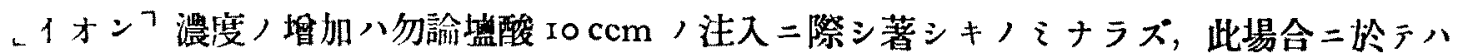

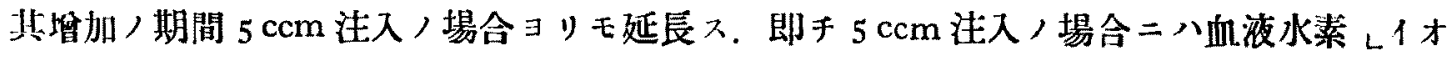
$2^{1}$ 濃度八鏆酸住入後 60 分 120 分二シテ注入前，狀態二恢復スルモ， $10 \mathrm{ccm}$ 注入，昜

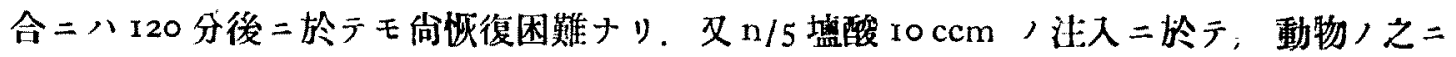

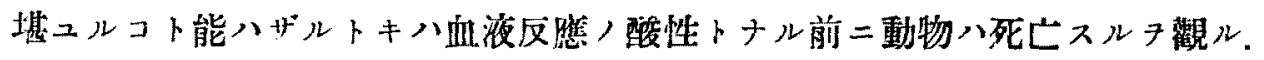

\section{7. 重炭酸 レナトリウム 血液水素 ᄂイオンフ 澧度}

柳田及ビ喜多 ${ }^{17}$ ，八家鬼静脈內二重炭酸 レナトリウム

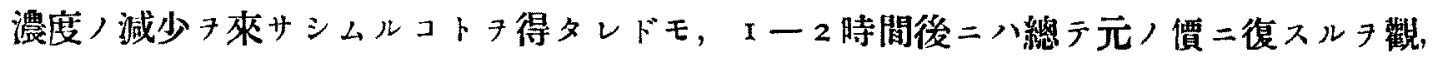

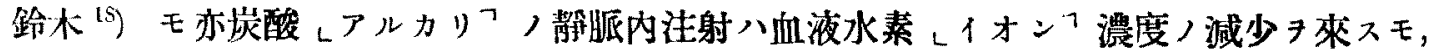

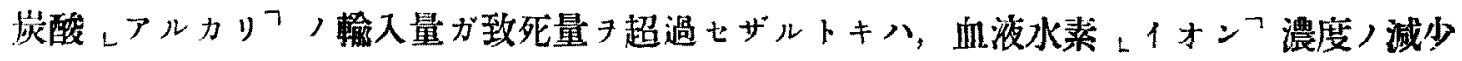
著シキ際ト雖モ，漸次正常二復スルョ觀タリト示フ

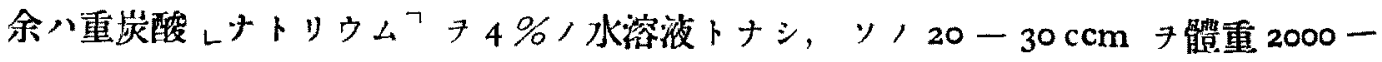
$2500 \mathrm{~g}$, 家鬼静脈內二注入シ，其注入直前及ビ注入 30 分，60分及ビ 120 分後二於ヶル血

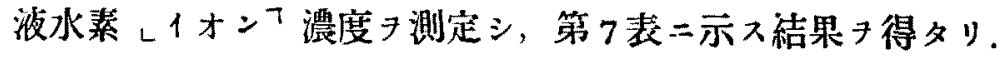

即チ $4 \%$ 重炭酸 レナトリウムフ溶液 $20 \mathrm{ccm}$ キ注入七ル場合二於テハ, 注入前血液 $\mathrm{P}_{\mathrm{H}}$ 7,34 ナリシモノガ注入後 30 分ニシテ7,40トナリタルモ, 60 分後二ハ7,35トナル7数タ 


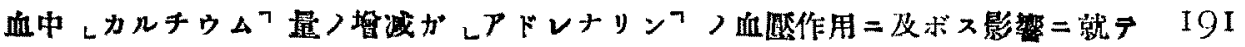

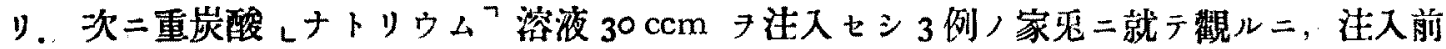

第 7 表 重炭酸 レナトリウムフ 龄脈內 注入啳ノ血液水素レイォンフ 渨度

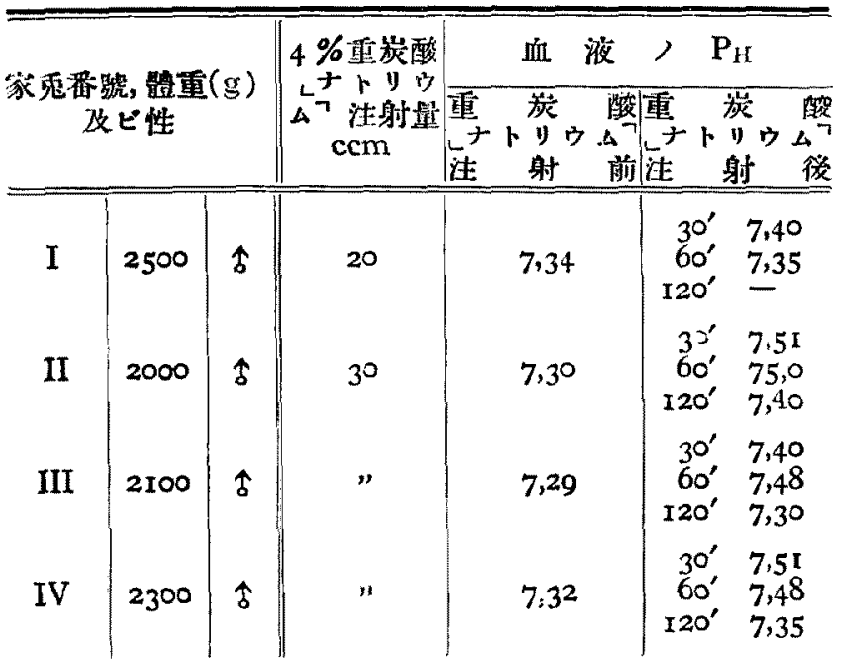

项液 $P_{H} 7,30$ ナリシ $\mathrm{I}$ 例ハ注入 後 30 分ニシテ $7.51=$ = 60 分後 二八7,50-, 120 分後 $=M 7,40$ トナルキ敬タリ。他ノ I例二於 テハ重炭酸レナトリウムフ 溶液 注入前血莅 $P_{\mathrm{H}} 7,29$ ナリシニ, 注入後 30 - シテ $7,4^{\circ}=60$ 分 後二八7,48=, 120 分後二八 $7,30 ト ナ ル 7$ 觀タリ。省他ノI 例二於亏注入前血液 $\mathrm{P}_{\mathrm{H}} 7,32+$

リシモ, 八注入後 30 分ニシテ $7,5 x=, 60$ 分後ニハ $7,48=, 120$ 分後二ハ 7,35 トル 觀タリ。

要之, 體重 2000 - $2500 \mathrm{~g}$ ，家鬼靜脈內二4\% 重炭酸 レナトリウム 注入ルルトキハ, 血液水素 レイオンフ濃度ハ一時減少スルモ，動物ハ之二堪一，血液水素 レイオンフ濃度ハ漱次元ノ價二復スルモノニシテ，最モ著シキ水素し1オンし濃度ノ減少 八重炭酸レナトリウム?溶液注入後 1 時間め内ニアリ。

\section{8. 血液水素 レイオンフ 濃度ヨ聕加セシメタル場合二 於ケル、アドレナリンフ 血壓作用}

Alpern ${ }^{19}$ ) 八家鬼耳殻血管灌流二際シ，灌流漰， $\mathrm{P}_{\mathrm{H}} 5,2-5,6$ 間二於テハレアドレ ナリンー，血管收縮作用八著シク減弱七ラレ， $P_{\mathrm{II}}$ 7,8-8,0，間二於テハレアドレナリンフ

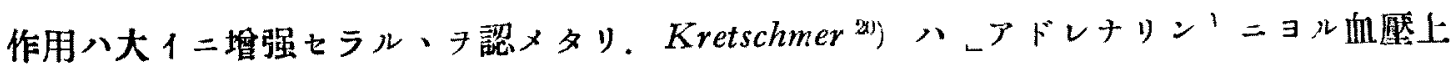

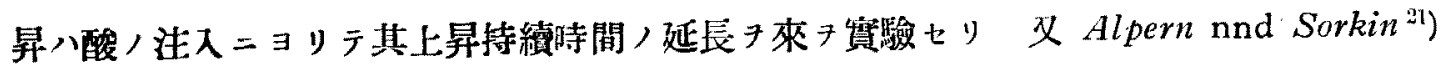

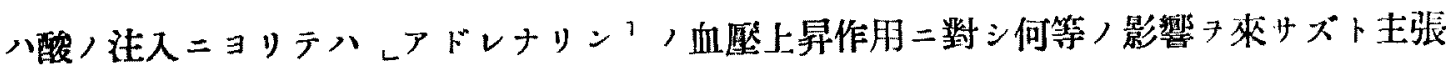
セり

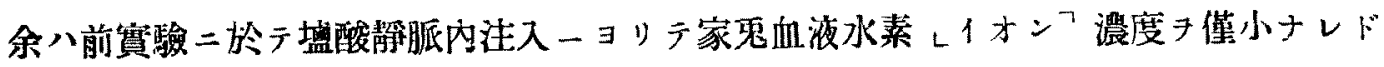

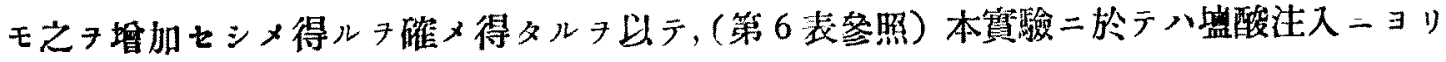

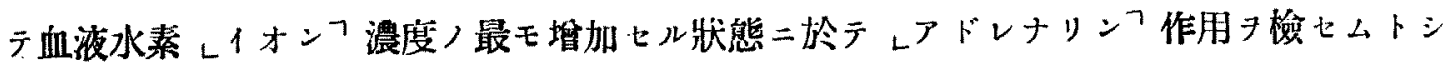




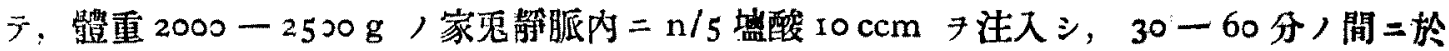
テレアドレナリンフ作用 フ檢查シタルニ第 8 表ノ如キ結果 7 得タリ.

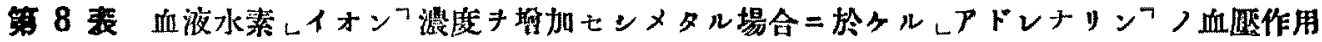

\begin{tabular}{|c|c|c|c|c|c|c|c|}
\hline \multirow{2}{*}{\multicolumn{3}{|c|}{ 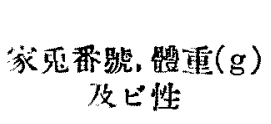 }} & \multirow{3}{*}{ 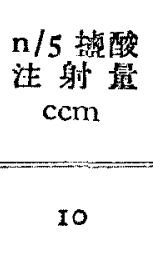 } & \multicolumn{4}{|c|}{ レPトレナリンフ反應 } \\
\hline & & & & \multirow{2}{*}{ 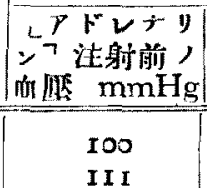 } & \multirow{2}{*}{ 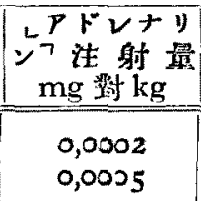 } & \multirow{2}{*}{ 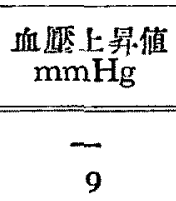 } & \multirow{2}{*}{ 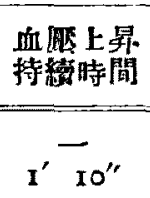 } \\
\hline I & 2200 & 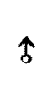 & & & & & \\
\hline II & 2000 & $\hat{s}$ & " & $\begin{array}{r}105 \\
95\end{array}$ & $\begin{array}{l}0,0002 \\
0,0005\end{array}$ & - & $-{ }^{\prime \prime \prime}$ \\
\hline III & 2400 & $\hat{\jmath}$ & " & $\begin{array}{l}80 \\
83\end{array}$ & $\begin{array}{l}0,0005 \\
0,00 \mathrm{r}\end{array}$ & $\overline{10}$ & $\mathrm{r}^{\prime}-\overline{35^{\prime \prime}}$ \\
\hline IV & 2200 & $\hat{\delta}$ & " & 100 & $0,00 \mathrm{r}$ & 10 & $\mathbf{I}^{\prime} 30^{\prime \prime}$ \\
\hline V & 2500 & $\hat{\sigma}$ & ” & So & $0, \infty \mathrm{I}_{\mathrm{I}}$ & 14 & $\mathbf{I}^{\prime} 30^{\prime \prime}$ \\
\hline$V I$ & 2200 & $\hat{s}$ & $"$ & 106 & $0,0 \mathrm{r}$ & $6_{4}$ & $2^{\prime} 15^{\prime \prime}$ \\
\hline VII & 2300 & $\hat{a}$ & $"$ & 84 & 0,01 & $5^{\circ}$ & $3^{\prime} 20^{\prime \prime}$ \\
\hline VIII & 2400 & $\uparrow$ & $"$ & 80 & $0,0 \mathrm{I}$ & 80 & $2^{\prime} \quad 15^{\prime \prime}$ \\
\hline
\end{tabular}

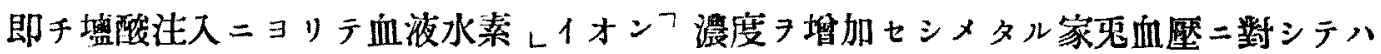
レアドレナリン'對 $\mathrm{kg} 0,0002 \mathrm{mg}$ 八無㪣ナリシモ，0,0005 mg ’3 例中 2 例二於テ 5 及ビ

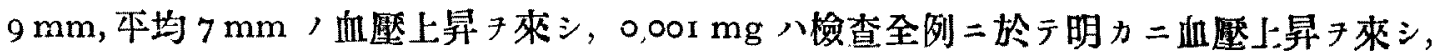
其上昇値八 $\mathrm{IO}-14 \mathrm{~mm}$, 平均 II mm, =シテ, 上昇特續時間八 $\mathrm{I}$ 分 30 秒一 $\mathrm{I}$ 分 32 秒，本均

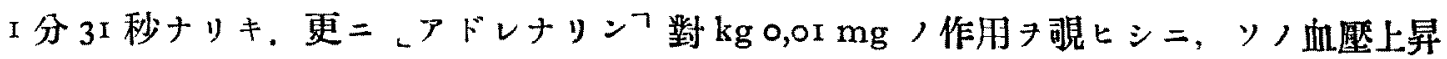
值八 $50-80 \mathrm{~mm}$, 本均 $65 \mathrm{~mm}=シ テ$, 上昇持績八 2 分 15 秒- 3 分 20 秒，本均 2 分 37 秒ナリキ。

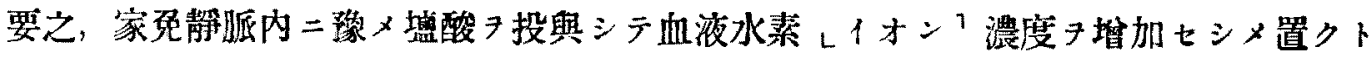

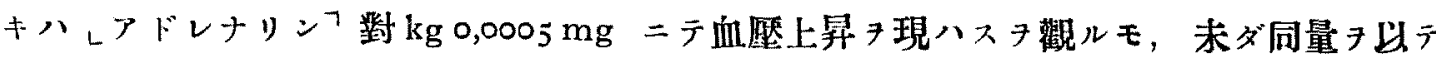

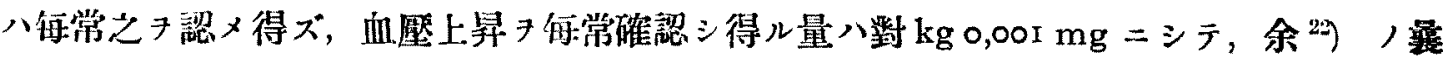

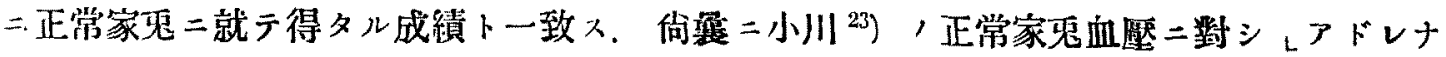

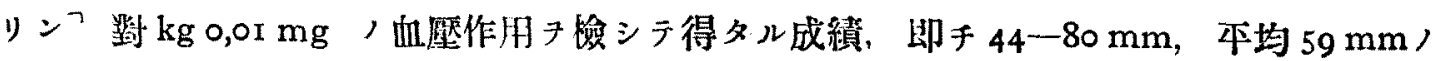
血壓上昇値卜 $\mathrm{I}$ 分 40 秒 -2 分 $\mathrm{5}$ 秒, 本均 $\mathrm{I}$ 分 55 秒，上昇持績二對スル余，櫒酸投興例 二於ケルしアドレナリンフ對 $\mathrm{kg} 0,01 \mathrm{mg}$ ，作用，即于血壓上昇值 50-80 mm，本均 65 $\mathrm{mm}$ 及ビ上昇持續時間 2 分 15 秒一 3 分 20 秒，本均 2 分 37 秒 7 比較スル二，血歴，上昇 八兩者ノ間二差アリト斷言シ能ハザルモ，其持縝八壇酸靜脈內投與例二於テ八正常家鬼二 
於ケルヨりモ若于延長スルキ観ル。

\section{9. 血液水素 ᄂイオンフ 濃度习減少セシメタル場合ニ 於ケルレアドレナリンフ ノ血壓作用}

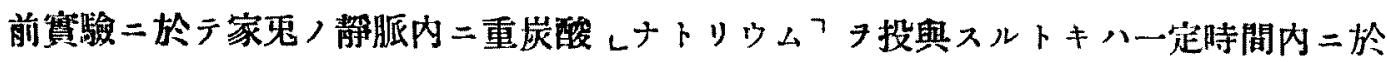
テ血液水素しイオン'賑度八減少スルキ確認シタリ.(第 7 表突照)

余ハ此血液水素，1オンフ濃度ノ減少ガ生體ニ於ヶルしアドレナリンフ作用二如何ナ

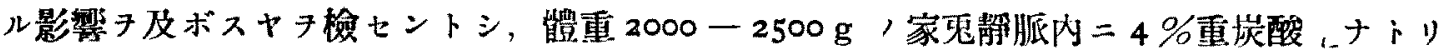

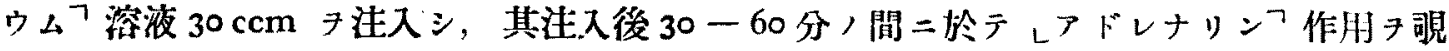
ヒシニ,レアドレナリンフ對 $\mathrm{kg} 0,00005 \mathrm{mg}$ 八全ク血壓上昇作用タ示サズ， 0,0001 $\mathrm{mg}$ 八 3 例中 $\mathrm{x}$ 例二於テ $5 \mathrm{~mm}$ ）血壓上昇丹來シ,他ノ 2 例二對シテハ無効ナリキ。次二 $0,0002 \mathrm{mg}$ 八全例二於テ明カ二血壓上昇チ來シ，其上昇值ハ $5-6 \mathrm{~mm}$ ，外圴 $5,3 \mathrm{~mm}$ ニシテ. 其上

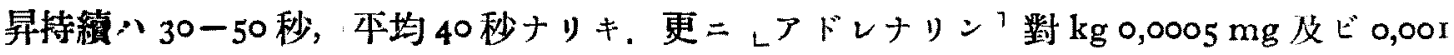
$\mathrm{mg}$ 八勿論確實二血壓上昇キ來シタルハ第 9 表二就テ觀レバ明カナり

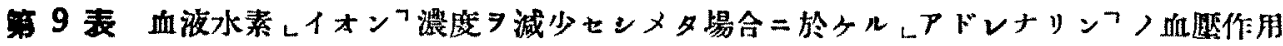

\begin{tabular}{|c|c|c|c|c|c|c|c|}
\hline \multirow{2}{*}{\multicolumn{3}{|c|}{$\begin{array}{c}\text { 家鬼番號, 䯏重 }(\mathrm{g}) \\
\text { 及ビ性 }\end{array}$}} & \multirow{2}{*}{ 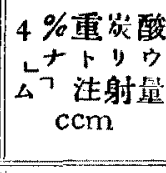 } & \multicolumn{4}{|c|}{ マアドレナリンフ反㫿 } \\
\hline & & & & LPV゙v+》 & เPトナナy & 血惩上:晅值 & 血䣆上昇 \\
\hline I & 2000 & $\hat{\delta}$ & 30 & $\begin{array}{l}78 \\
80 \\
78\end{array}$ & $\begin{array}{l}0,00005 \\
0,0001 \\
0,0002\end{array}$ & $\begin{array}{r}- \\
5 \\
5\end{array}$ & $\begin{array}{l}- \\
20^{\prime \prime} \\
30^{\prime \prime}\end{array}$ \\
\hline II & 2000 & $\hat{s}$ & $"$ & $\begin{array}{l}85 \\
90\end{array}$ & $\begin{array}{l}0,0001 \\
0,0002\end{array}$ & $\overline{6}$ & - \\
\hline III & 2200 & $\delta$ & $"$ & $\begin{array}{l}84 \\
84\end{array}$ & $\begin{array}{l}0,000 \mathrm{r} \\
0,0002\end{array}$ & $\overline{5}$ & $\overline{50}^{\prime \prime}$ \\
\hline IV & 2100 & $\hat{\jmath}$ & " & $\begin{array}{l}80 \\
92\end{array}$ & $\begin{array}{l}0,0005 \\
0,001\end{array}$ & $\begin{array}{r}14 \\
8\end{array}$ & $\begin{array}{l}40^{\prime \prime} \\
45^{\prime \prime}\end{array}$ \\
\hline V & 2100 & 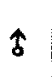 & $"$ & $\begin{array}{l}82 \\
90\end{array}$ & $\begin{array}{l}0,0005 \\
0,001\end{array}$ & $\begin{array}{l}10 \\
12\end{array}$ & $\begin{array}{l}50^{\prime \prime} \\
5^{\prime \prime \prime}\end{array}$ \\
\hline VI & 2300 & $\hat{\delta}$ & $"$ & $8 r$ & 0,01 & 90 & $\mathbf{I}^{\prime}$ \\
\hline VII & 2500 & $\hat{\delta}$ & $"$ & 104 & $0,0 \mathrm{r}$ & 66 & $\mathbf{I}^{\prime}$ \\
\hline VIII & 2500 & $\hat{s}$ & " & 97 & $0,0 I$ & 79 & $I^{\prime} \quad 25^{\prime \prime}$ \\
\hline
\end{tabular}

次ニ レアドレナリンフ $\mathrm{kg} 0,01 \mathrm{mg}$ 八極メテ著明二作用シ，其血壓上昇値ハ $66-90$ $\mathrm{mm}$, 平均 $78 \mathrm{~mm}$ 二及ビ, 其持續八I 分一 I 分 25 秒, 平均 I 分 8 秒尹示セり。

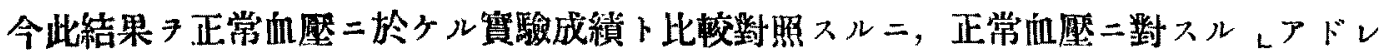




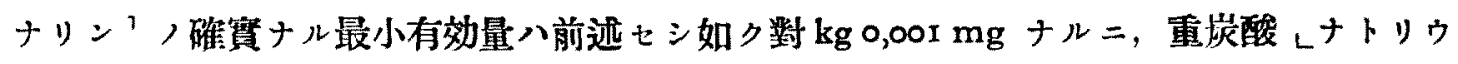

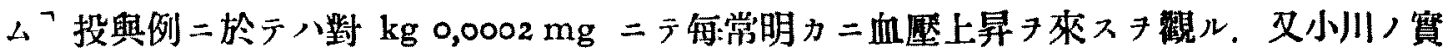

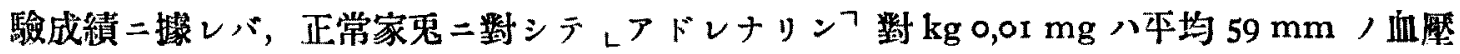

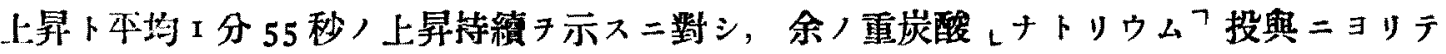
血腹水素レイオンフ漫度キ減少セシメタル例二於テハ本均 $78 \mathrm{~mm}$ ，血厴上昇卜本均 I 分

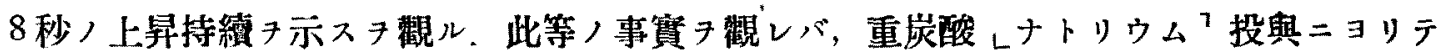

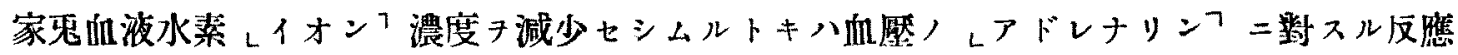

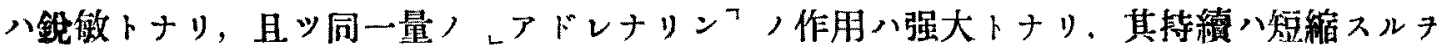
識ル。

\section{0. 血中 ᄂカルチウム 量增加セシメタル場合ニ}

\section{於ケルレアドレナリンフ /血壓作用}

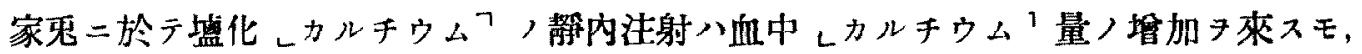

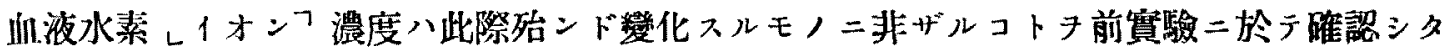

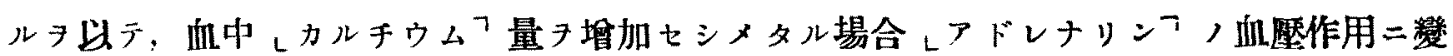
化习來サバ，這ハ獨りレカルチウムフ，坦量ノ篇メナリト䚴フコトタ得ベシ。

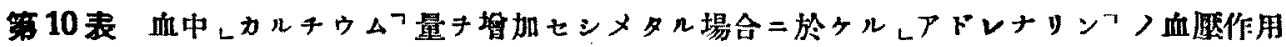

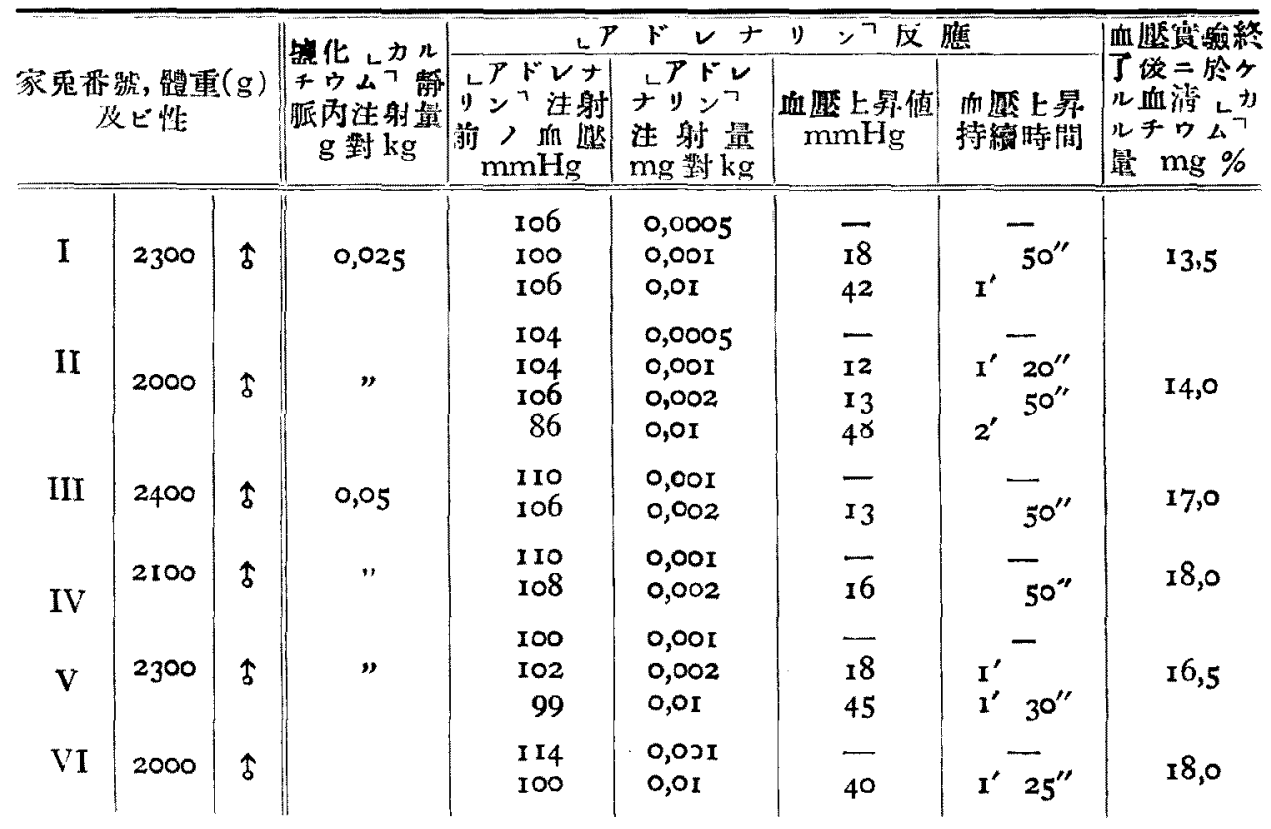




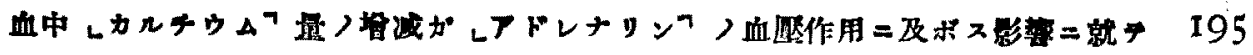

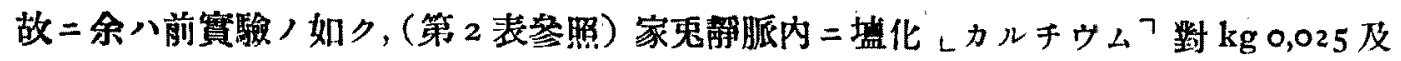

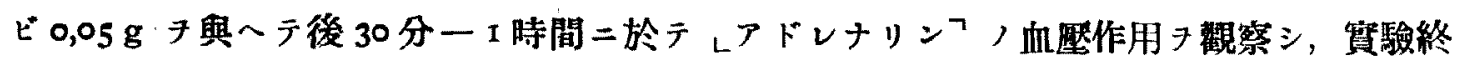

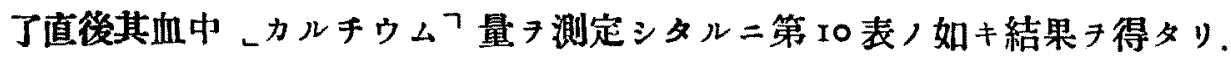

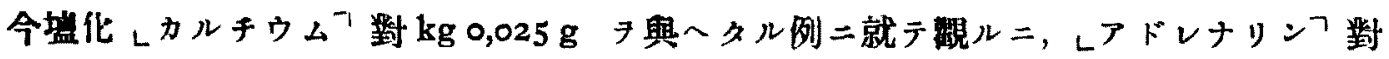

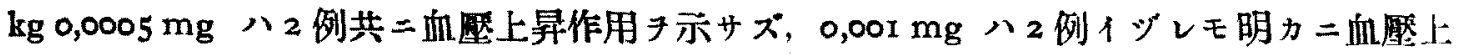

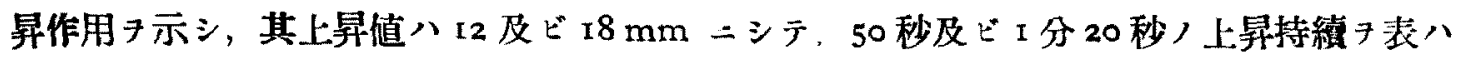

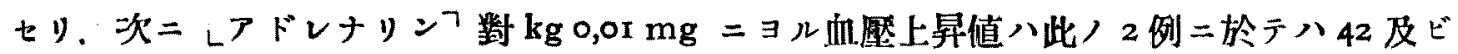
$48 \mathrm{~mm}$, 本均 $45 \mathrm{~mm}$ 二シテ. 上昇持結ハI 及ビ 2 分, 本均 $\mathrm{I}$ 分 30 秒ナリキ。

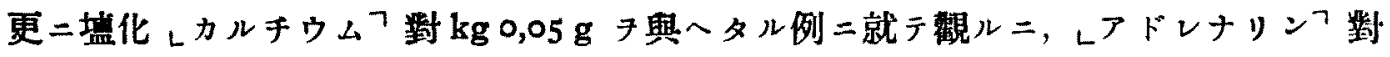

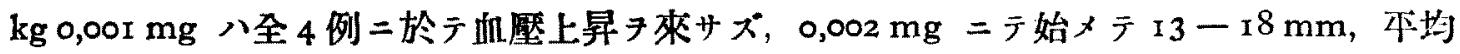
$15,6 \mathrm{~mm}$ ，血壓上昇キ示シ，50秒ー $\mathrm{r}$ 分，本均 55 秒閒上昇ヨ維持セり少レアドレナリ ンᄀ o,or mg ニヨル血壓上昇值い 2 例二於テ 40 及ビ $45 \mathrm{~mm}$, 本均 $42 \mathrm{~mm}=シ テ$, 其上开 持螋八I分 25 秒及ビ I 分 30 秒，本均 1 分 27 秒ナリキ。

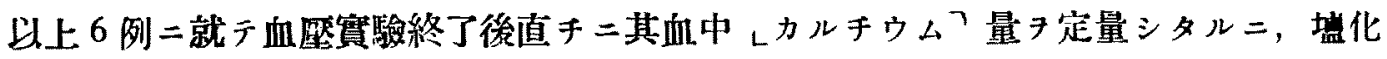

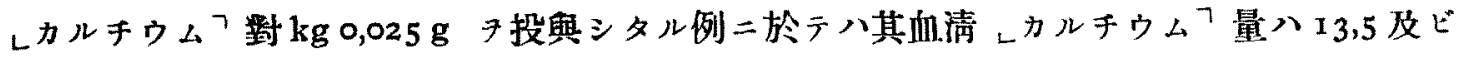

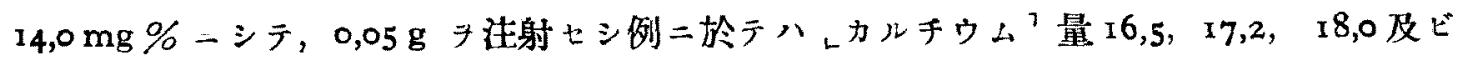
$18,0 \mathrm{mg} \%$ \%キ.

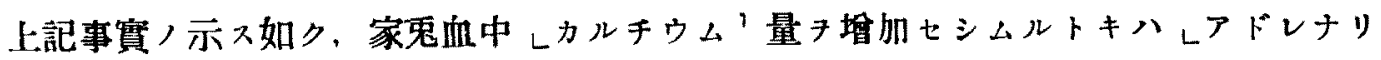

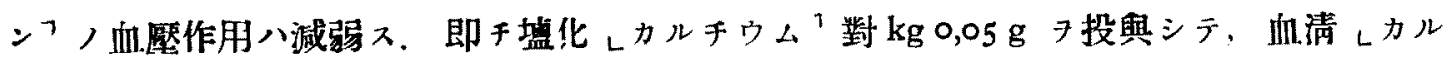
チウムフ量尹 $(16,5-18,0 \mathrm{mg} \%=)$ 增加七シムルトキハ, 血壓キ上昇シ得ルしアドレナ リンフ，最小有効量八正常時ノモノ二比シテ確實二增大シ，每常血壓上昇尹現ス確實ナル 最小有効量八数 $\mathrm{kg} 0,002 \mathrm{mg}=シ テ$, 正常時ノモノ、2 倍二當ル. 更二一定量ノレアドレ ナリンフ（對 $\mathrm{kg}$ 0,or mg），作用尹正常時ノソレト比較シ（192 頁參照）著明二㸓レル尹 知ル。

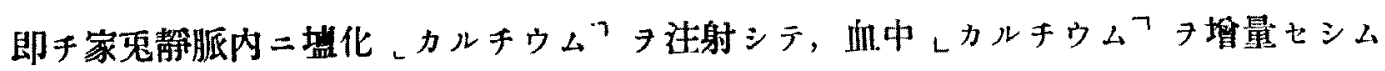
ルトキハレアドレナリンフノ血㭫作用八減弱スルチ識ル。

\section{1. 血中 ムカルキウム 7 量ヨ減少セシメタル場合二}




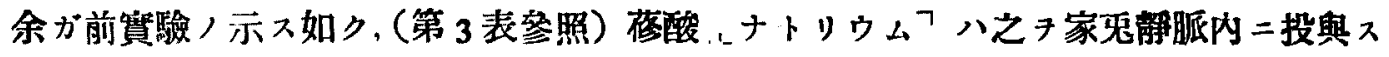

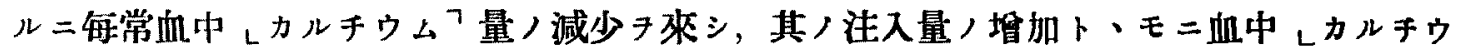

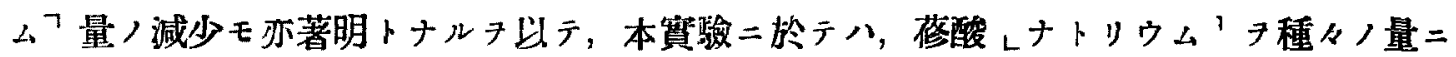

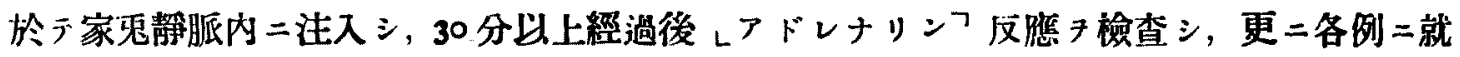
テ血壓實驗終了後直キニ血中レカルチウム? 量キ測定シタリ。

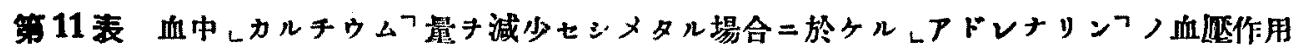

\begin{tabular}{|c|c|c|c|c|c|c|c|c|}
\hline \multicolumn{3}{|c|}{ 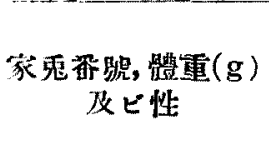 } & 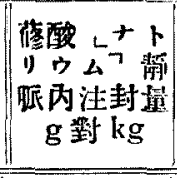 & 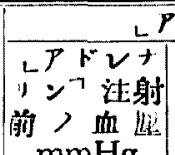 & 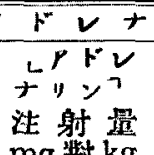 & $\begin{array}{c}\text { 血呕上两·值 } \\
\mathrm{mmHg}\end{array}$ & 血题上显 & 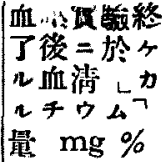 \\
\hline I & 2200 & $\uparrow$ & 0,01 & $\begin{array}{l}82 \\
88 \\
80 \\
88\end{array}$ & $\begin{array}{l}0,0001 \\
0,0002 \\
0,0003 \\
0,01\end{array}$ & $\begin{array}{r}- \\
5 \\
10 \\
90\end{array}$ & $\begin{array}{lr}I^{\prime} & 5^{\prime \prime} \\
I^{\prime} & \text { I } 5^{\prime \prime} \\
3^{\prime} & \text { I }{ }^{\prime \prime}\end{array}$ & 8,0 \\
\hline II & 2100 & $\hat{\sigma}$ & $"$ & $\begin{array}{l}82 \\
82 \\
80 \\
84\end{array}$ & $\begin{array}{l}0,0001 \\
0,0002 \\
0,0003 \\
0,01\end{array}$ & $\begin{array}{r}- \\
5 \\
90\end{array}$ & $\begin{array}{l}- \\
\mathbf{I}^{\prime} \\
3^{\prime} \quad 10^{\prime \prime}\end{array}$ & 7,4 \\
\hline III & 2200 & $\hat{s}$ & $"$ & $\begin{array}{r}\text { II } 5 \\
\text { IIO } \\
\text { Io6 } \\
81\end{array}$ & $\begin{array}{l}0,0001 \\
0,0002 \\
0,0003 \\
0,01\end{array}$ & $\begin{array}{r}- \\
5 \\
79\end{array}$ & $\begin{array}{l}- \\
\overline{1} \\
1^{\prime \prime} 5^{\prime \prime} \\
2^{\prime} 25^{\prime \prime}\end{array}$ & 7,6 \\
\hline IV & 2200 & $\hat{\delta}$ & , & $\begin{array}{l}84 \\
82 \\
86\end{array}$ & $\begin{array}{l}0,0002 \\
0,0003 \\
0,01\end{array}$ & $\begin{array}{r}5 \\
8 \\
67\end{array}$ & $\begin{array}{ll}\mathbf{I}^{\prime} & \text { I } 5^{\prime \prime} \\
\mathbf{I}^{\prime} & 35^{\prime \prime} \\
3^{\prime} & 10^{\prime \prime}\end{array}$ & 8,2 \\
\hline V & 2400 & 今ิ & 0,02 & $\begin{array}{l}80 \\
76 \\
82 \\
95\end{array}$ & $\begin{array}{l}0,001 \\
0,002 \\
0,003 \\
0,01\end{array}$ & $\begin{array}{r}- \\
5 \\
7 \\
37\end{array}$ & $\begin{array}{l}\mathbf{I}^{\prime} \\
\mathbf{I}^{\prime} \\
\mathbf{I}^{\prime} 40^{\prime \prime}\end{array}$ & 5,3 \\
\hline VI & 2000 & $\hat{\sigma}$ & " & $\begin{array}{l}86 \\
85 \\
82 \\
95\end{array}$ & $\begin{array}{l}0,001 \\
0,002 \\
0,003 \\
0,01\end{array}$ & $\begin{array}{r}-8 \\
6 \\
37\end{array}$ & $\begin{array}{l}\mathbf{I}^{\prime}=\mathbf{I O}^{\prime \prime} \\
\mathbf{I}^{\prime} \\
\mathrm{I}^{\prime} \quad 50^{\prime \prime}\end{array}$ & 5,8 \\
\hline VII & 2200 & $\hat{\delta}$ & " & $\begin{array}{r}88 \\
85 \\
100 \\
100\end{array}$ & $\begin{array}{l}0,001 \\
0,002 \\
0,003 \\
0.01\end{array}$ & $\begin{array}{r}- \\
8 \\
20\end{array}$ & $\begin{array}{l}I^{\prime}, 20^{\prime \prime} \\
I^{\prime}, 30^{\prime \prime} \\
I^{\prime} \quad 50^{\prime \prime}\end{array}$ & 5,6 \\
\hline VIII & 2300 & ๙ิ & 0,03 & $\begin{array}{l}96 \\
99 \\
93 \\
87\end{array}$ & $\begin{array}{l}0,001 \\
0,002 \\
0,003 \\
0,01\end{array}$ & - & $\begin{array}{l}- \\
\overline{1^{\prime}} \\
\mathrm{I}^{\prime} \\
35^{\prime \prime}\end{array}$ & 4,6 \\
\hline IX & 2100 & $\hat{\jmath}$ & " & $\begin{array}{r}90 \\
94 \\
100 \\
86\end{array}$ & $\begin{array}{l}0,001 \\
0,002 \\
0,003 \\
0,01\end{array}$ & $\begin{array}{l}- \\
- \\
10 \\
34\end{array}$ & $\begin{array}{l}- \\
I^{\prime} o^{\prime \prime} \\
I^{\prime} 5^{\prime \prime}\end{array}$ & 4,9 \\
\hline $\mathrm{X}$ & 2100 & $\hat{\delta}$ & $"$ & $\begin{array}{l}96 \\
96 \\
98 \\
95\end{array}$ & $\begin{array}{l}0,001 \\
0,002 \\
0,003 \\
0,01\end{array}$ & $\begin{array}{r}- \\
- \\
38\end{array}$ & $\begin{array}{l}- \\
\overline{55^{\prime \prime}} \\
35^{\prime \prime}\end{array}$ & $5, \mathrm{I}$ \\
\hline
\end{tabular}

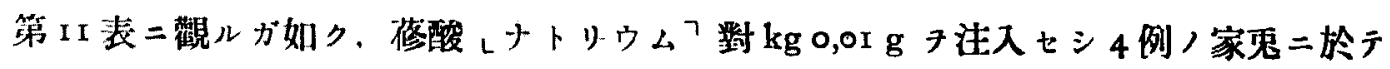




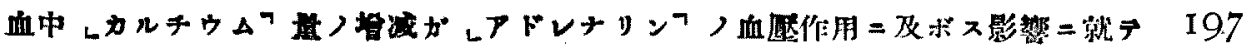

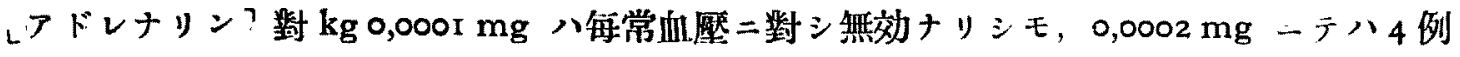

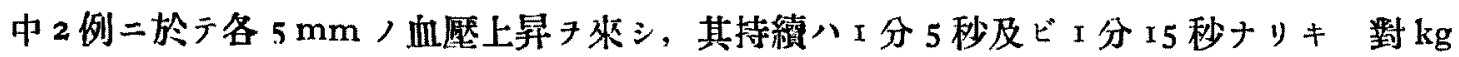

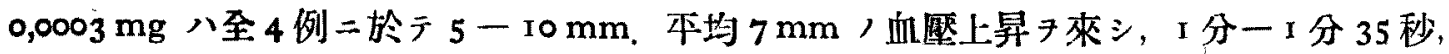

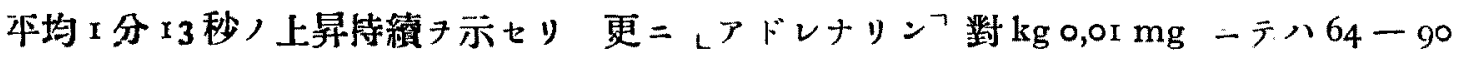
$\mathrm{mm}$, 平均 $80 \mathrm{~mm}$ ，血壓上昇尹示シ， 2 分 25 秒- 3 分 10 秒，本均 2 分 58 秒，上昇持緢

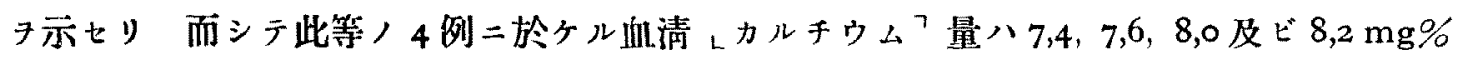
等ナリキ

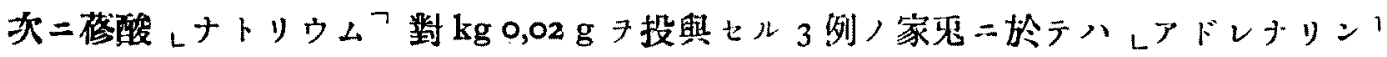

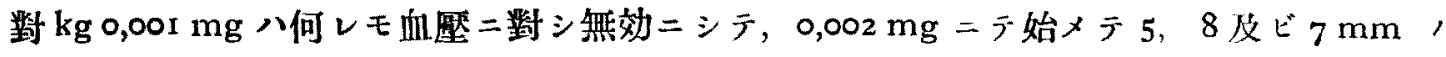
血壓上昇キ示シ， $0,003 \mathrm{mg}$ 二テハ6, 7 及ビ $8 \mathrm{~mm}$ / 血壓上昇 7 來シ, $0,01 \mathrm{mg}$ 二テハ 20 ,

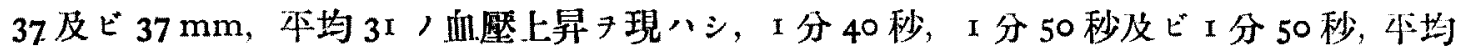
I 分 46 秒間其上昇尹持續七リ．此等 3 例二就テ血壓實羷終了直後其血清 レカルチウム

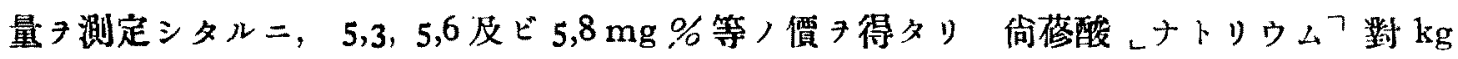

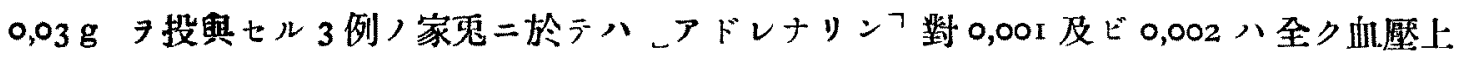

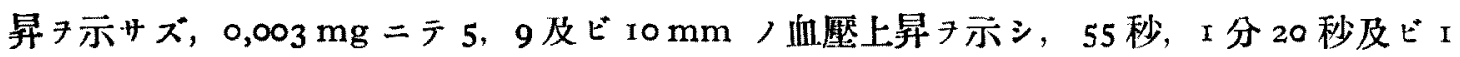

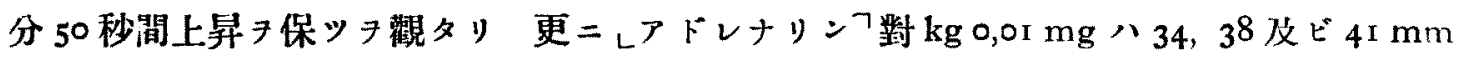

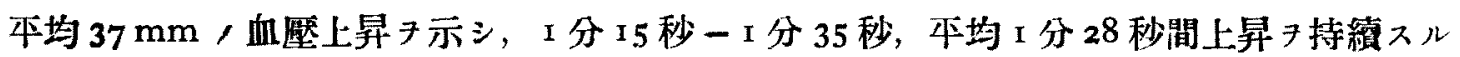
チ觀タリ。

此等 3 例二就テ血歷實驗終了直後其血清 レカルチウムา 量チ测定シタルニ，4,6, 4,9 及ビ 5 , I mg\%等ノ價タ示シタリ.

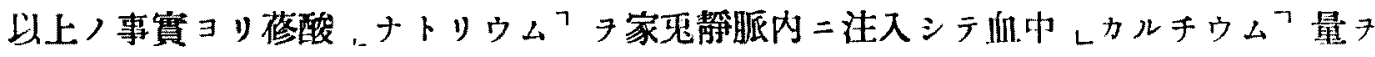

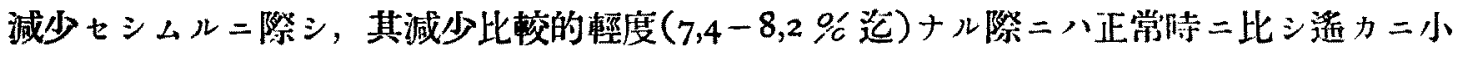

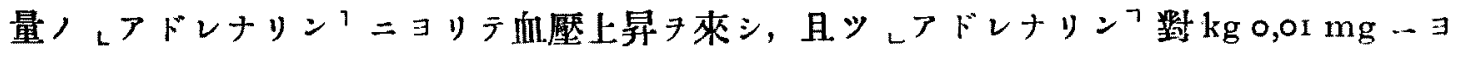

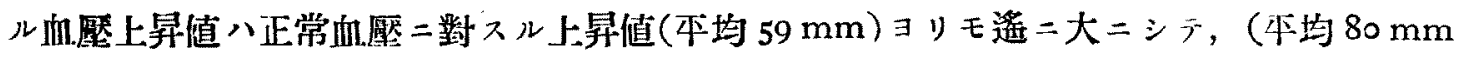
上昇持續時間モ亦秒々延長ス 然レドモ葆酸レナトリウムフノ注入量子更二㙕加シ，血中

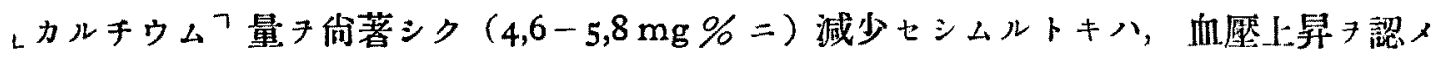

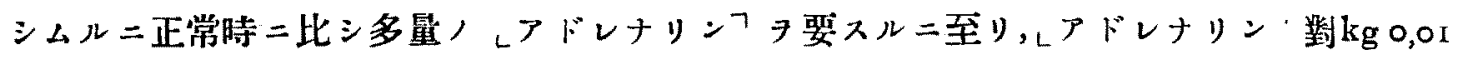
$\mathrm{mg}=\exists ル$ 血厤上昇值モ亦正常時ノソレ二及バザルニ至ル 而シテ血清 レカルチウム ${ }^{7} 5,3$ 一 5,8 mg \% /間二於テハレアドレナリンา，血壓上昇二要スル最小有効量八對 $\mathrm{kg} 0,002$ 


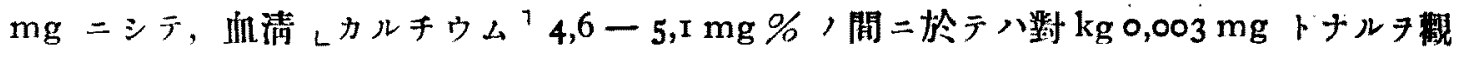
ル（正常血码二對シテ確賽ナル最小有効量八對 $\mathrm{kg} 0,00 \mathrm{mg}$ )

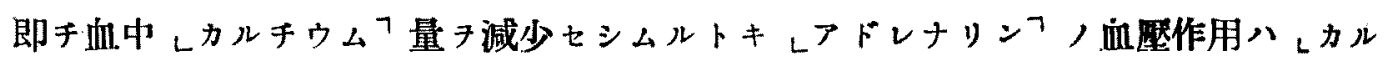
チウム

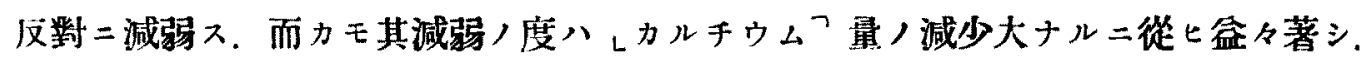

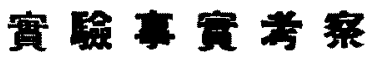

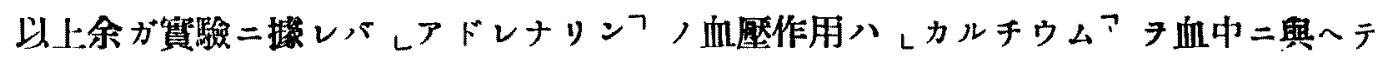

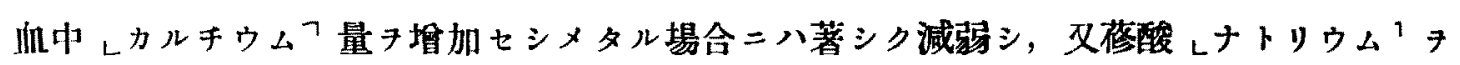

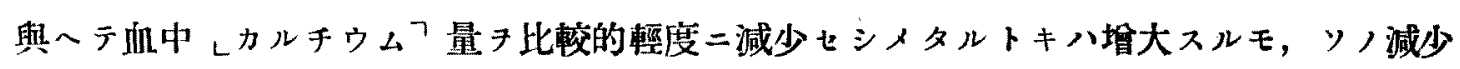
キシテー定範園タ超へテ更二著シクナストキハ正反對ニレカルキウム 量ノ正常ナルトキ

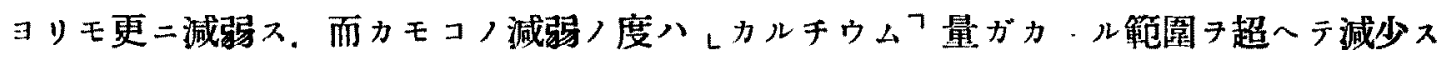

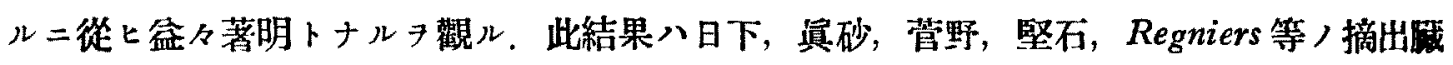
器灌流䁈羷ノ成縝卜全ク一致ス。

然ルニHollo und Weiss 八レカルチウム

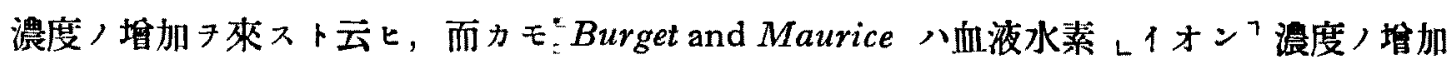

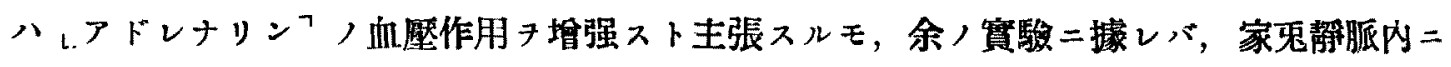

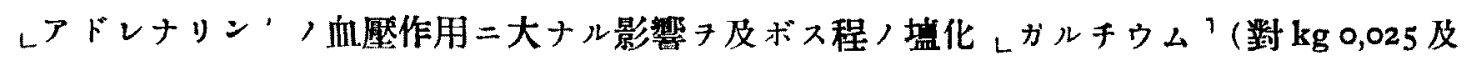

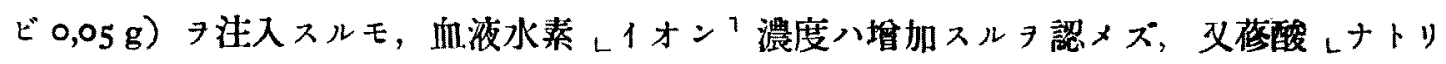

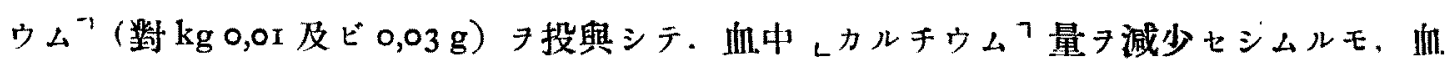

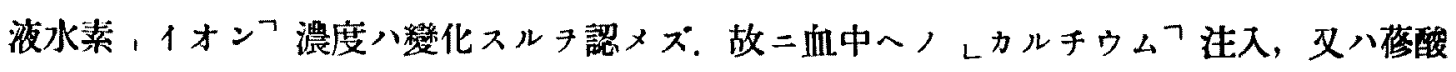

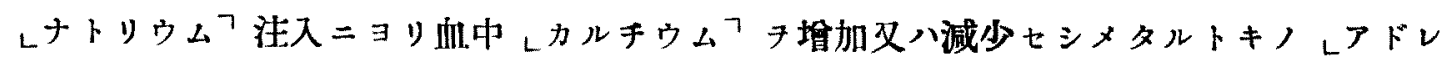

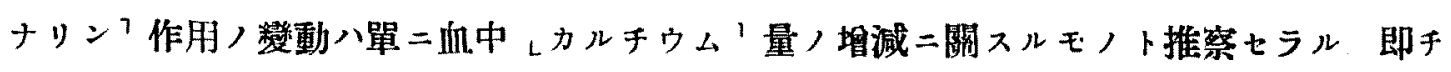

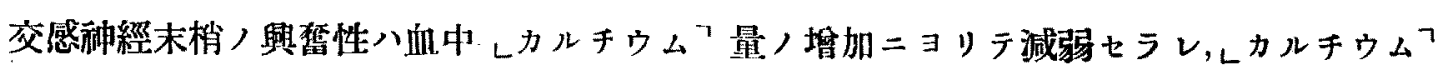
，比較的輕度，減少ニヨリテ强盛トナルモ，其，減少度ガ一定範園フ超ユルトキハ減弱セ ラル.

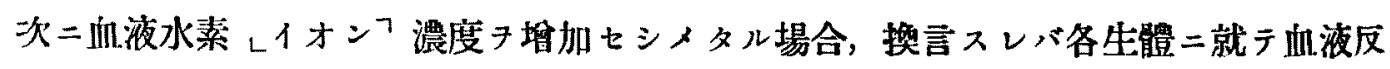

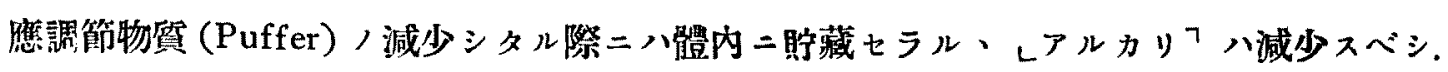

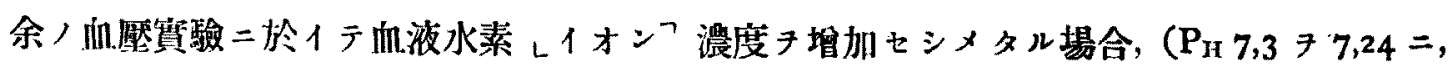




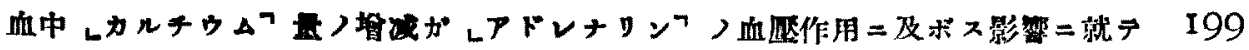

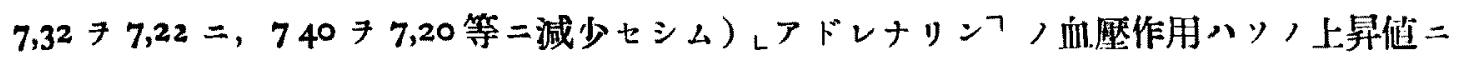
於テハ正常時二比シ大差ナキモ，ソノ作用時間ノ若于延長スル⿻認ムルハ, カ、ル場合二 ハレアドレナリンフ，破壇ノ行ハレ難キニヨルベク、反之體內二多量ノレアルカリフォ注:

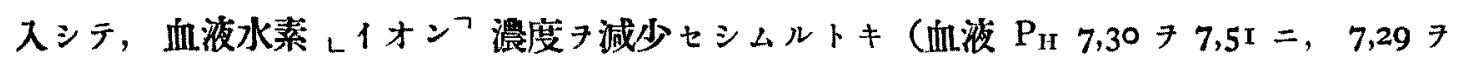

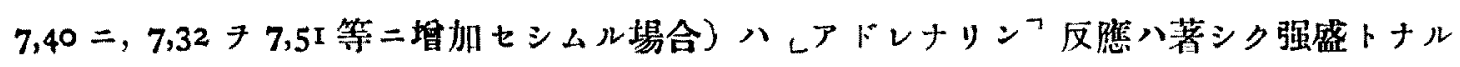
モ，ソノ作用ハ一渦性ニシテ，烅壓上昇持續時間ハ正常時同量ノしアドレナリンフニヨル

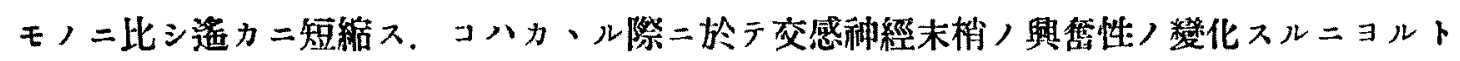
モ考へラレザルニアラネド，體內 レアルカリフ，篔加ニヨリ血中二於テレアドレナリンフ 盐基ノ﨎出チ容易且速カナラシムルニモヨルナランカ.

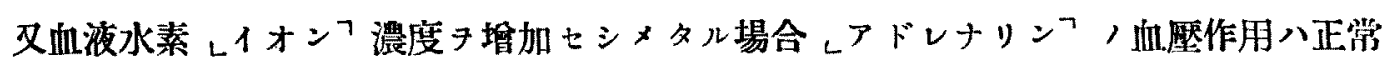

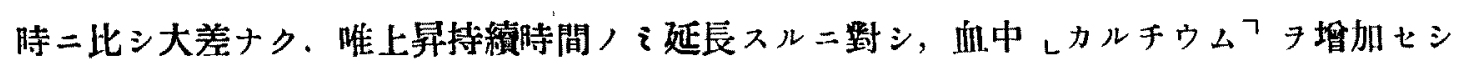

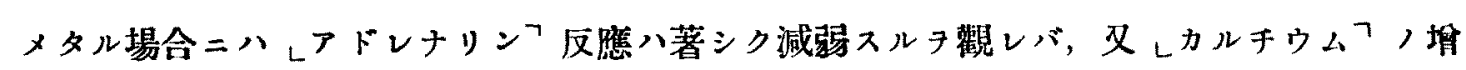

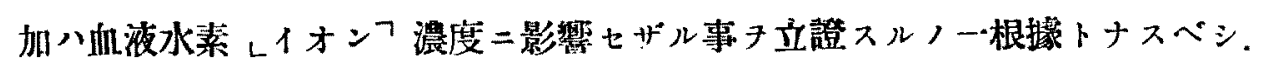

\section{宾䛗事宽總括}

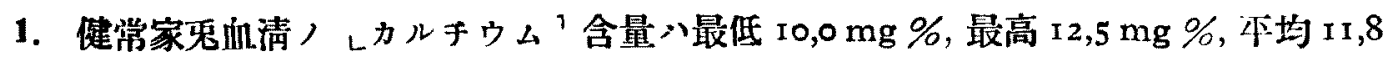

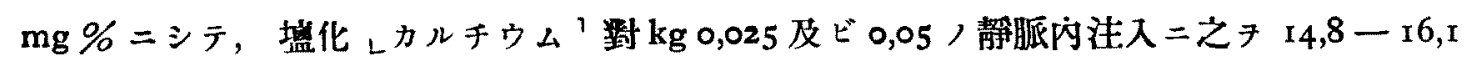

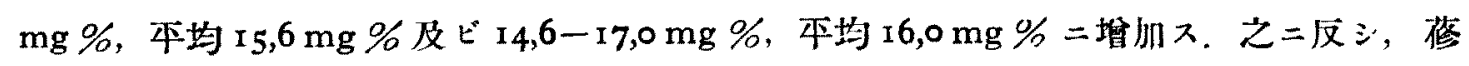

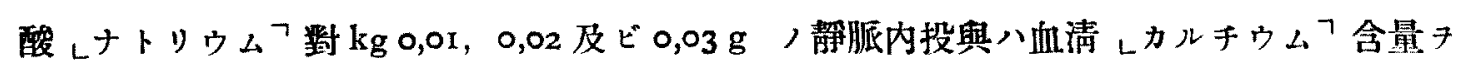
$7,2-7,9 \mathrm{mg} \%$, 本拄 $7,5 \mathrm{mg} \%, 5,5-5,8 \mathrm{mg} \%$, 平均 $5,6 \mathrm{mg} \%$ 及ビ 4,6-5,1 mg\%, 本 均 $4,8 \mathrm{mg} \%=$ 減少 .

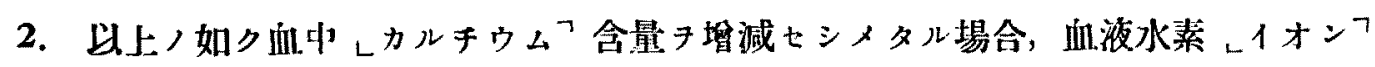
濃度ハ㱠ンド婪化スルキ認メズ.

3. 體重 2000-2500 $\mathrm{g}$ ，家鬼静脈內二 $\mathrm{n} / 5$ 盐酸 5-10 ccm 7 注入三， 30 分, 60 分及 ビ 120 分後二血渡水素レイオンフ浱度丹計测スルー, 注入後 30 分二於テ該レイオンフ濃度 ノ增加最モ著シク，4\%重炭酸レナトリウム、20-30 ccm チ注入七ル場合二ハ, 注入後 I 時間以內二於テ最著シキ血液水素 レイオンフ濃度ノ減少ヨ來ス

4. 盐酸, 靜脈內注入後, 向液水素レイオンフ濃度, 最モ著シク增加セル時期二於テ, 向壓二對スルレアドレナリンフ，最小有効量ハ正常時ト暴ラズ，又同一量レアドレナリ 


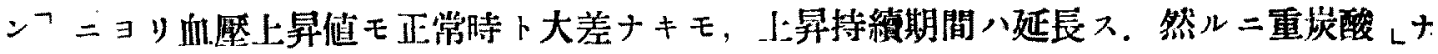

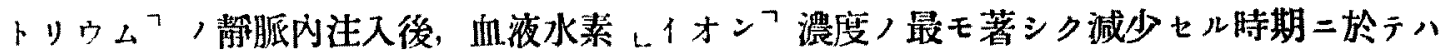
血厴二對スルュアドレナリン゙／最小有効量八正常時ヨリモ遥カ二小（對 $\mathrm{kg} 0,0002 \mathrm{mg}$ )

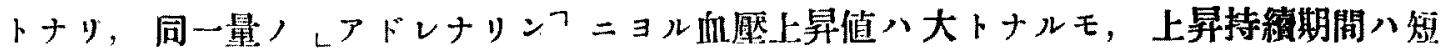
縮 ス

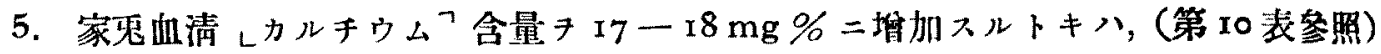

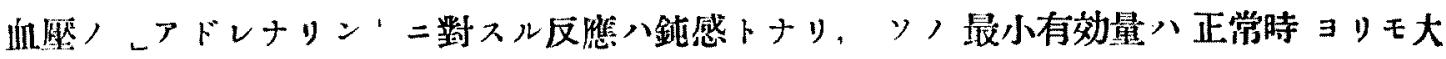

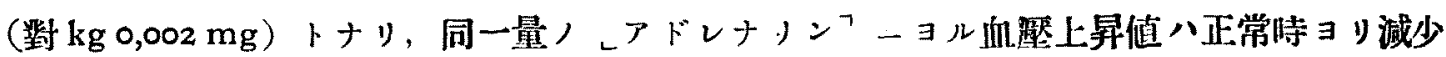

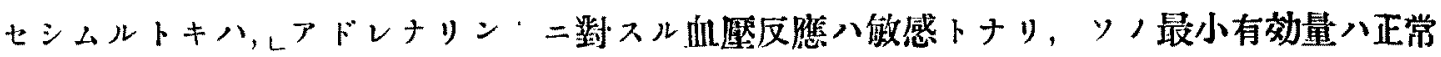
時ヨリモ甚シク小（對 $\mathrm{kg} 0,0002 \mathrm{mg}$ ) トナル，而シラ同一量ノレフドレナリンフニヨル血

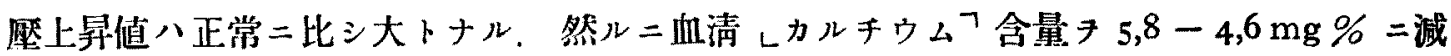

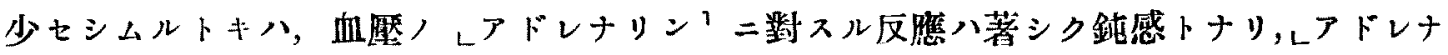

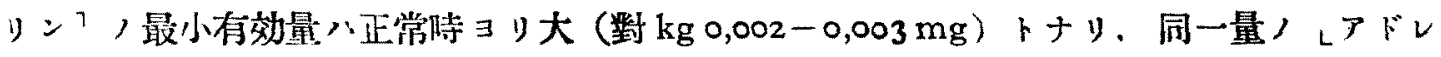
ナリンフーヨル血壓上昇值八遥カ二正常時ノソレニ及バザルニ至ル（第１１表曑照）

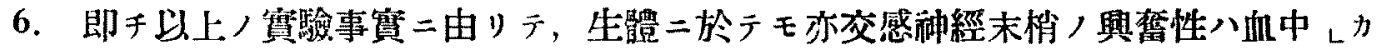

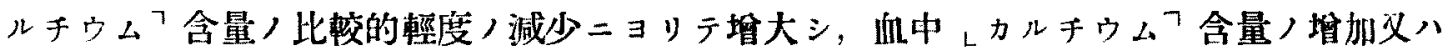
一定範圍テ超へラ減少スルトキハ減退スルタ吉證シ得タリ。

\section{引用書 目}

I) Chiari u. Fröhlich, Arch. f. experim. Pathol. u. Pharmakol. Bd. 64, S. 214, I9Ir.

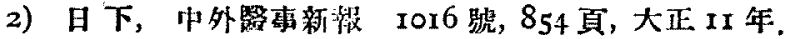

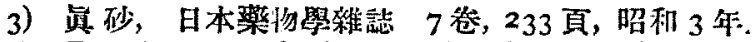

4) Regniers, Arch. intern. de Pharmacodyn. et de Thérap. T. 31, p. 303, 1926.

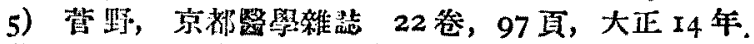

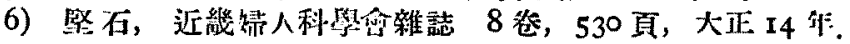

7) Kolm u. Pick, Pflügers Arch. Bd. 189, S. 137, 192 r.

8) Kylin, Zeitschr. f. d. ges. experim. Med, Bd. 45, S. 208, 1925.

9) Hol.o u. Weiss, Biochem. Zeitschr. Bd. I6o, S. 237 , 1925.

Io) Burget and Maurice, Americ. Journ. of Physiul. Vol. 81, p. 113, I927.

I I) De Waard, Biochem. Zeitschr. Bd. 97, S. I79, Igig.

12) Michaelis, Praktikum der Physikalischen Chemie II Aufl. S. 139, 1922.

13) Marianne 'Richter-Quittner, Zeitschr. f. d. ges. experim. Med. Bd. 45, S. 479, 1925.

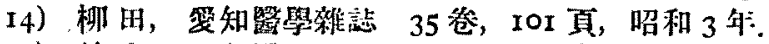

15）鈴木, 日新距學 15 巷, 262 頁, 大价 4 年.

16) Ito, Tohoku Journ. of experim. Med. Vol. 8, p. 75, I926.

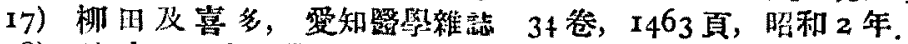

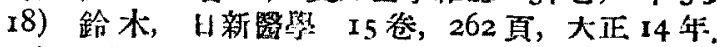

19) Alpern, Pfliïrers Arch. Bd, 205, S. 578, I924.

20) Kretschmer, Arch. f. d. experim. Pathol. u. Pharmakol. Bd. 57, S. 438, 1907.

21) Alpern u. Sorkin, Zeitschr. f. d. ges. experim. Med. Bd. 45, S. 648, 1925.

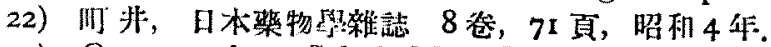

23) Ogazva, Acta Schol. Med. Univ. Imp. in Kioto.Vol. 7, p. 29r, 1924. 